\title{
Suitability Evaluation System for the Production and Sourcing of Agricultural Commodities
}

\author{
Isabel Jaisli, Patrick Laube, Sonja Trachsel, Pascal Ochsner, Sarah Schuhmacher \\ Institute of Natural Resource Sciences, Zurich University of Applied Sciences, Waedenswil, Switzerland
}

\begin{abstract}
This article presents CONSUS (Connecting for Sustainable Sourcing), a modular GIS-based decision-support system for producing and sourcing agricultural commodities. The system extends the classic FAO land evaluation approaches in three specific dimensions: (i) the sustainability dimension: the extended suitability analysis reaches beyond purely biophysical suitability and integrates ecological, economic and social suitability; (ii) the value chain dimension: the focus of suitability analysis includes further upstream activities relevant for product trading; (iii) the spatio-temporal dimension: the inclusion of an adaptive global crop cycle model and scale-specific suitability modules allow for multi-scale suitability evaluation that considers cropping seasons; The system was implemented as a flexible tool set, featuring knowledge databases, GIS toolboxes, and supporting data processing modules. CONSUS emerged from a series of third party funded applied research projects. Two of these serve in this article as case studies illustrating the capabilities of the system: one global case study on the sourcing of hazelnuts, and one regional case study on suitability of soybean production in Rwanda.
\end{abstract}

\section{Introduction}

The reality of the food business from production to trade and consumption currently faces enormous changes. Increasing pressure on land, growing populations, changing environmental conditions due to climate change, increasing global trade, and changing food patterns are calling for new strategies and fast adaptations in the agricultural market. The identification of suitable production opportunities under the changing conditions is becoming an increasingly important but complex task for both farmers and agribusinesses. The need for land use planning due to changing needs and pressures, as well as increasing competition between different uses for the same land, led to the development of the 'Framework for land evaluation' (FAO, 1976). The method describes the process of matching crop requirements with land qualities to identify the suitability of production at a given location. A key element of the method is the classification of land suitability, which is defined as the land's fitness for a certain crop or use.

Since its first description land evaluation has been applied in a variety of studies (Alabi et al., 2012; Verdoodt and Van Ranst, 2006; Zolekar and Bhagat, 2015) and has been further developed to account for changing needs as well as benefiting from advancements in spatial data availability and computing power (Elsheikh et al., 2013; FAO, 2007; Rossiter, 1996). New and increasingly accessible information sources, capturing the biophysical but crucially also the socio-economic properties of potential production sites, offer previously unseen opportunities for inclusive decision support systems for agricultural production and sourcing. Geographic Information Systems (GIS) combined with database technology offer an efficient and effective way of integrating the vast and heterogeneous data sources required to cover the multiple information dimensions included in current interpretations of the FAO framework. This article builds upon the theory of land evaluation and suitability assessment, as well as previous work on their implementation in software applications in GIS and spatial-decision support systems (SDSS).

\subsection{Land suitability}

As initially pointed out by the FAO (1976) and later echoed by the same organization (FAO, 2007) biophysical and socio-economic factors are both crucial in defining suitable and sustainable agricultural land use. Thus, on the one hand, the land evaluation system proposed in this article includes biophysical factors such as climate, landscape and soil. An important step forward in biophysical land evaluation was contributed by Sys et al. (1991), providing alternative methodologies for the matching of multiple land qualities and their respective crop requirements as well as a comprehensive catalogue of specific crop requirements. The majority of land evaluation studies are limited to the assessment of biophysical factors, due to the availability of data as well as their direct and predictable effect on crop productivity.

On the other hand socio-economic factors are also important to include in a land evaluation system, as the sustainability of the production of a crop depends on its compatibility with an existing farming system (Dal Belo Leite et al., 2015). The compatibility of a farming system with new land use depends on economic, political, legal, and cultural circumstances (Mandryk et al., 2015), on prevailing risks and opportunities farms are facing 
(Heumann et al., 2013), and on their endowment with different livelihood assets, such as human, social, financial, physical and natural capital (Nijbroek and Andelman, 2015; Pretty, 2008). Thus, a wide range of factors - on the global, regional and local levels - influence the socio-economic suitability of the production of a certain crop.

Several studies have shown that the integration of socio-economic factors into land evaluation is crucial because biophysical and socio-economic suitability can differ (He et al., 2013), and sustainable agricultural production depends on the suitability of both aspects. Land evaluation studies offering broader and more detailed socioeconomic information provide decision-makers with a better basis for planning (Alabi et al., 2012). So far, suitability evaluations including socio-economic factors have been applied on the regional or local level (e.g. Alabi et al., 2012; Ayorinde et al., 2015). But from a global sustainable sourcing perspective, land evaluation including both socio-economic as well as biophysical site characteristics is needed. The insights gained on the global scale can then be sharpened in a more detailed land evaluation on the regional level using regional data.

\subsection{GIS-based multi-criteria evaluation and spatial decision support systems in agriculture}

Geographic information systems (GIS) are an established tool for integrating heterogeneous spatial information through the metaphor of space, or more precisely through a shared geographic reference system (Longley et al., 2011; Worboys and Duckham, 2004). Land evaluation has been a signature GIS application for decades (Chen et al., 2010), and has been applied in a multitude of academic and applied research areas. The typical procedure of choice for formalizing spatial decision problems is the so-called multi-criteria evaluation method (Carver, 1991). Multi-criteria evaluation (MCE) operationalizes a set of suitability criteria through appropriate spatial variables and combines those variables into a spatially explicit suitability assessment, in the most simple case a suitability map (Malczewski, 2006, 1999) or in more complex spatial decision support systems, SDSS (Mendas and Delali, 2012).

Since its peak decade around 2000, MCE has seen a constant stream of applied suitability studies in agricultural applications. Many of them are based on the FAO framework, with minor to major adjustments accounting for technological advancements and improved data sources. Recent methodological progress includes sensitivity studies and the inclusion of expert systems (Elsheikh et al., 2013), a significant increase in the breadth of considered criteria (Mendas and Delali, 2012), as well as the integration of previously unavailable input data through the use of remote sensing, e.g. soil moisture and soil depth data (Zolekar and Bhagat, 2015). Multi-criteria suitability evaluation has furthermore proved to be an application field for the conceptually elegant but in practice rather complex fuzzy set theory, allowing for gradual memberships instead of mere discrete suitability class boundaries (Elsheikh et al., 2013; Qiu et al., 2014; Sharififar et al., 2016).

Clearly, technological progress and better data sources have lifted classic land evaluation to a new level. However, most studies still focus on the biophysical aspects of the sourcing problem and neglect the equally important socioeconomic properties of the targeted areas. Furthermore, most GIS-based SDSSs for agricultural production are tailored to very specific regional application scenarios, resulting in tools with limited transfer potential to other areas or even other scales and which mostly neglect limitations that become relevant in the trading and transporting of goods.

\subsection{Scope and objectives}

The main focus of this research project is to develop a flexible tool for assessing the spatially explicit production and sourcing potentials of crops, considering not only the biophysical suitability of potential sites but also socioeconomic suitability aspects and considerations of environmental protection. By including not only production criteria, but also trade and compliance issues, CONSUS goes beyond the mere identification of production opportunities and considers limitations within the entire supply chain. In detail, the contributions of this article are three-fold:

- Section 2 presents our extension of the FAO suitability framework, adopting a holistic suitability perspective covering both biophysical and socio-economic suitabilities.

- Section 3 describes a flexible tool set implementing the suitability evaluation process, linking GISworkflows in toolboxes to knowledge sources developed and managed in databases.

- Section 4 puts the concept and its implementation to the test through two application case studies covering both the global and the regional scale: a search for suitable sites for hazelnuts (Corylus avellana L.) worldwide and for soybeans (Glycine max L. Merrill.) in Rwanda. 


\section{The CONSUS suitability model}

CONSUS is designed as a decision support system for agribusinesses and for rural developments and is implemented in a GIS. It is designed to evaluate the suitability and sustainability of (crop) production and sourcing opportunities. Current land use, biophysical criteria, such as soil and climate, and other factors influencing trade and business compliance are considered, as well as agricultural systems and other socio-economic conditions. Results help identify suitable sites for selected crops and existing restraints in production, as well as the overall sustainability impacts.

Through its design as a flexible multi-modular and multi-scale sequential framework, CONSUS allows for application in a variety of contexts and scales. The overall model contains five core modules (Figure 1) to assess several suitability aspects of crop production at, and sourcing from selected sites. On the one hand CONSUS examines the suitability of a certain crop by matching biophysical site characteristics with crop requirements. On the other hand, CONSUS integrates business and compliance perspectives with land use and infrastructure preliminaries, with the aim of assessing the socio-economic suitability of crops under consideration. The selection of modules used in a specific case depends on the case-specific questions, data availability, and project scale. When searching globally for suitable areas for a certain crop, coarse global data sets can be used. When, by contrast, the focus is narrowed down to finding specific production sites in a given country, regional or even local data with much finer granularities can be used.



Fig 1. CONSUS model. The simplified graph shows the major data flows in the CONSUS model. The modules of the matching process can be combined in a flexible way, allowing for model adaptations regarding the analysis scale and variable data availabilities.

\section{$2.1 \quad$ Suitability evaluation process}

The suitability assessment in CONSUS is based on the theory of land evaluation (FAO, 2007, 1976; Sys et al., 1991). It is built on the core element of matching crop requirements with site qualities to assess the land's fitness for a selected crop. This general approach is used in both the biophysical and socio-economic assessment of crop suitability, with adaptations explained in chapters 2.2 and 2.3 .

The suitability evaluation in CONSUS consists of the following four steps (Figure 1):

(1) Niche description: The description of crop requirements is based on the socio-environmental niche concept (Heumann et al., 2013; Ojiem et al., 2006). Niche in this context describes the region as a multidimensional space consisting of environmental and socio-economic factors that influence the performance of a certain crop. A crop's successful adaptation into an existing farming system is not only determined by its productivity but also by its compatibility with the socio-economic situation in a given location. Following the approach of land evaluation 
(FAO, 1976; Sys et al., 1991), suitability classes must be defined for each factor: S1 (highly suitable), S2 (moderately suitable), S3 (marginally suitable) and N (not suitable). CONSUS works with three types of requirement data: a) requirements which are crop specific (or crop variety specific), but universally valid, b) requirements which are also case or context specific and c) requirements which are neither crop nor context specific. Universally valid requirements are mainly biophysical factors (such as precipitation or soil fertility requirements) whereas socio-economic factors are mainly case or context specific (e.g. farm size or level of mechanization). One cornerstone of CONSUS's universal and flexible applicability lies in collecting the universally valid crop requirement data in an easily accessible knowledge base connected to the subsequent GIS tools (the crop $D B$, see chapter 3 ).

(2) Site description: The second step of the CONSUS analysis sequence consists of assembling the multi-layered characterization of the study area. The goal here is to underpin every aspect of the niche, as defined above, with corresponding data. Two information sources are considered here. First, site properties comprising, for example, the precipitation or the soil fertility distribution in the study area. All this spatial information is stored in the $g e o D B$. The second form of information comes as tables, further characterizing socio-economic properties of the study area, stored in the $\operatorname{socEcoDB}$. Although in most cases not explicitly spatial in the first place, such data typically has some form of spatial reference (e.g. a district name), allowing its inclusion in the CONSUS analysis process.

(3) Matching: The actual matching is performed for each single factor individually. The single-factor matching step describes the classification of each land unit into the respective suitability value $\mathrm{S} 1$ to $\mathrm{N}$ and is based on the functional relationships that exist between the specific land characteristics and the socio-environmental niche of the crop (FAO, 1976; Rossiter, 1996). In the process of individually matching each factor, interactions or relations between the factors are ignored. Although not considering interactions represents a considerable simplification of the reality, it can also reduce a significant source of error arising from wrongly described interactions (Sharififar et al., 2016).

(4) Aggregation. The aggregation of the different factors is then realized by the Maximum Limitation Method (MLM) according to Sys et al. (1991). In this method the suitability of a land unit is determined by rating the factor with the lowest rate (Figure 2). This approach follows Liebigs's law of the minimum, stating that crop performance is controlled by the most limiting factor (Sharififar et al., 2016). Aggregation of various factors follows a stepwise approach, e.g. precipitation, temperature, humidity and insolation are aggregated into climate suitability, which, together with soil \& land suitability is aggregated to biophysical suitability. The MLM is a globally established land evaluation method. The main advantage is its simplicity, which allows application even by non-experts (de la Rosa and van Diepen, 2002). The CONSUS model not only aims at assessing the suitability class for every location, but also at identifying the most limiting criteria resulting in this class. In Figure $2 b$, the bottom layer summarizes both the aggregated maximum limitation of the entire input stack (ML) and the specific input layer (.layer) causing that maximum limitation. Both pieces of information are valuable and combined in the notation ML.layer. For the raster cell stack at the front left (in light grey) the maximum limitation is S3 from Insolation (I).

(a)

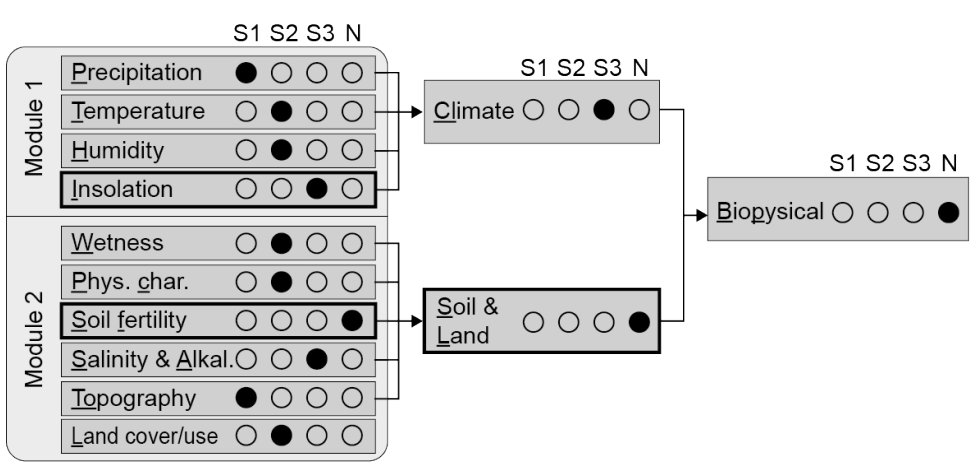

(b)

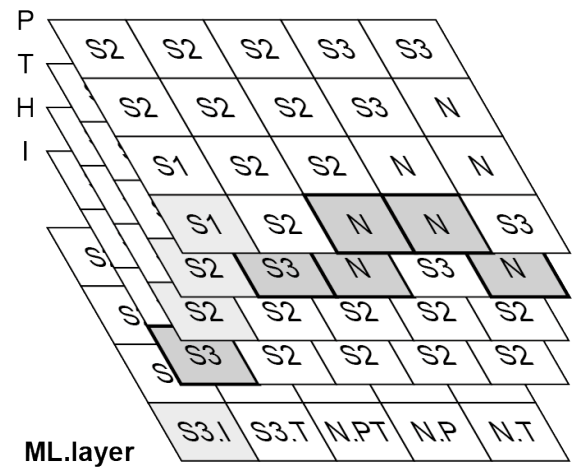

Fig 2. Single-factor matching and aggregation. (a) Stepwise aggregation for biophysical suitability. The maximum limitation in module 1 is $\mathrm{S} 3$ from insolation, in module 2 it is $\mathrm{N}$ from soil fertility. These two results are then aggregated into an overall maximum limitation $\mathrm{N}$ for biophysical suitability. (b) Spatial perspective. The front left corner of the stack (in light grey) corresponds to module 1 in (a), where the overall 'Climate' suitability S3 originates from Insolation (I), combined in the notation S3.I.

In addition, not only can the actual suitability be assessed, but also the potential suitability. The actual suitability assesses the suitability of the land under current, unchanged conditions. However, this evaluation neglects the opportunities for land improvement, be they of biophysical (e.g. soil fertility) or socio-economic (e.g. introduction 
of new technologies) nature. The potential suitability takes these possible improvements into consideration and simply assesses the suitability through a) exclusion of improvable factors (e.g. soil acidity is not included in the assessment) or b) adapting the requirements (niche description) in respect to the potential improvements (soil acidity is still included in the assessment, but threshold values between suitability classes are defined under consideration of appropriate management practices, e.g. lime application). For example, excluding soil fertility from module 2 evaluation in Figure 2 would lift the current suitability class $\mathrm{N}$ to a potential suitability class S3.

\subsection{Biophysical suitability}

Biophysical suitability is the aggregation of climate suitability and soil \& land suitability. The assessment of the biophysical suitability of a crop for a land unit represents the core function of the overall assessment, as these factors directly affect the biomass production (as a prerequisite for yield, income and livelihoods). The biophysical requirements of the crops are assessed based on literature and expert knowledge. Although the plant-physiological requirements of the crops are given, as mentioned above, in practice, the actual biophysical conditions can in many cases be improved in situ (e.g. many soil parameters).

Depending on the specific crop requirements, climate suitability (module 1) is assessed considering basic climatic parameters such as average yearly precipitation, temperature, humidity and insolation. Due to the nature of plants, several climatic requirements are time specific, depending on the plant's crop cycle (e.g. precipitation in first month, minimum temperature during flowering). To be able to also include such crop cycle specific climatic requirements in assessments of large areas that express temporal shifts of the seasons, the CONSUS crop cycle optimizer has been developed (Figure 3). The optimizer allows the integration of both basic and crop cycle specific climatic requirements in a dynamic way, searching for the optimal suitability by iterating, for example, through all possible starting dates of the growing season. Every iteration takes a different starting month and recalculates the climate suitability for that month, specially adjusting derived climatic requirements (such as precipitation in first month). The combination of all iteration results takes every individual grid cell into account and shows (a) the highest achievable suitability, and (b) the month(s) that achieve this optimal suitability. In other words, the crop cycle optimizer models the optimal crop cycle for each land unit. The principle is depicted in Figure 3, illustrating, for example, the calculation of a certain climatic suitability parameter that is a function of the starting month of the growing season. Every starting month results in a suitability layer (Jan, Feb, Mar, ...). The optimizer then picks the highest score (Max). Analogous to Figure 2b, the respective optimal starting months can also be extracted: here they are May and June.

Soil \& land suitability (module 2) encompasses factors such as wetness, physical characteristics, fertility, salinity $\&$ alkalinity, topography, and land cover. Again, many parameters are basic geospatial variables such as soil types from soil maps or elevation from digital terrain models. Also for soil \& land suitability more complex parameters may have to be derived or precomputed from other data sets. Most prominent examples here include derived topography parameters such as slope, aspect, and curvature. Additionally, these modules assess whether agricultural production is generally possible at a given site based on the current land use (e.g. urban areas or primary forests can be excluded). 
(a)

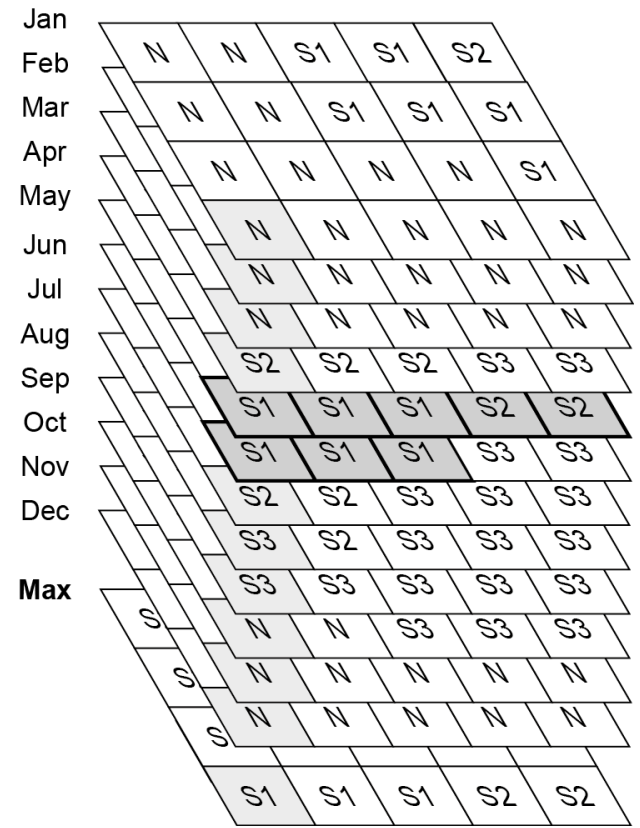

Fig 3. Crop cycle optimizer: The front left corner of the stack (in light grey) illustrates finding the optimal starting months, resulting in the best suitability class, here S1 starting in May and June.

\subsection{Socio-economic suitability}

The socio-economic evaluation encompasses three modules: restrictions and infrastructural suitability (module 3), farming system suitability (module 4), and business and compliance suitability (module 5, see Figure 1). Modules 4 and 5 are scale-dependent mutual modules, with module 4 applied for local and regional scales and module 5 for global scales.

The restriction and infrastructural evaluation (Module 3 ) is used to include legal and infrastructural restrictions. Legal restrictions are, for example, protected areas that prohibit agricultural use. Infrastructural restrictions are, for example, lack of roads, long transportation distances or lack of processing facilities.

The farming system evaluation (Module 4) assesses on the regional level whether the production of a certain crop fits into an existing farming system, considering specific socio-economic factors. This can also include the likelihood that management practices to improve biophysical factors ('Potential suitability') will be adopted into the existing system. Information about current farming systems is either taken from national/regional statistics or is provided or ascertained by experts. Regional land suitability is evaluated by comparing socio-economic land use types (FAO, 1985; see Table 1) with the required socio-economic niche conditions of a certain crop.

Table 1 Checklist of socio-economic factors that can be included in the description of land use types (adapted from FAO, 1985)

\begin{tabular}{ll}
\hline Site characteristics & Description \\
\hline Crops and Livestock & $\begin{array}{l}\text { Cropping system (single, multiple or compound), cultivation practices (land } \\
\text { preparation, tillage, harvesting, weeding etc.), livestock (use for traction, milk, } \\
\text { meat, manure, forage requirements etc.) }\end{array}$ \\
$\begin{array}{l}\text { Market Structure } \\
\text { Technology and Practices }\end{array}$ & $\begin{array}{l}\text { Irrigation, labor intensity, technical skills and attitudes (Experience, response to } \\
\text { innovation and change, literacy), mechanization and farm operations, material } \\
\text { inputs }\end{array}$ \\
Farm size and shape & $\begin{array}{l}\text { Farm size, different land utilization types by land size, fragmentation of } \\
\text { holdings, different irrigation types by land size }\end{array}$ \\
Lwnership and Rights & $\begin{array}{l}\text { Land tenure (freehold, communal, individual, traditional), water rights (state or } \\
\text { private ownership, traditional rights, sales of water etc.) }\end{array}$ \\
\hline
\end{tabular}

Factors included in the model are selected based on their relevance for the evaluation of the respective farming system regarding a specific crop under certain circumstances, the availability of data and expert knowledge (Alabi et al., 2012). 
The business and compliance evaluation (module 5) assesses from a global perspective whether conditions allow the agricultural production proposed or sourcing from a specific country. The evaluation builds upon existing country indices with relevance to agricultural production and sourcing. On the one hand indices regarding economic efficiency are included and on the other hand the evaluation comprises indices describing risks regarding social responsibility related to agricultural production and sourcing. The evaluation reflects which countries are more prone to difficulties in meeting social and ecological standards and which ones have barriers to setting up an economically successful business. The business and compliance evaluation allows the selection of indices as required by a specific case study. An example is given in table A2, Annex A. Module 5 applies indices for business and compliance suitability globally. Differences and disparities between countries and regions are integrated in the model in module 4 evaluating farming system suitability.

Finally, the biophysical and the socio-economic suitability can be integrated into an overall suitability.

\subsection{Model output}

CONSUS offers three different types of output: Suitability maps, limitation maps, and site assessments (e.g. site portraits or suitability spiders). Maps can depict intermediate single-factor suitabilities (e.g. temperature T), aggregated suitabilities (e.g. Biophysical suitability Bp) or overall suitability, integrating the biophysical and socio-economic assessment (Figure 4). Suitability maps show for each land unit the calculated suitability value (S1 to N). Alternatively, the potential suitability can be mapped, excluding for example Soil fertility Sf (Figure 4). Finally, limitation maps illustrate not only the suitability class but also the most limiting factor for each land unit. In the example in Figure 4, the maximum limitation for the biophysical suitability is $\mathrm{N}$ and results from Soil fertility Sf, the maximum limitation for the socio-economic suitability Se is S2 and results from Transport (Bp.N.Sf; Se.S2.Tr).

\begin{tabular}{|c|c|c|c|c|}
\hline Climate: & S3 & & & \\
\hline Soil \& L Land: & $\mathrm{N}$ & Biophysical: & & \\
\hline \multicolumn{2}{|c|}{ Restrictions \& Infrastructure: S2 } & \multirow[b]{2}{*}{ Socioeconomic: S2 } & Suitability: & $N\{$ Bp.N; Se.S2\} \\
\hline \multirow{2}{*}{ Buusiness \& $\underline{\text { Compliance: }}$} & S1 & & Potential Suitability [-Sf] & S3 \{Bp.S3; Se.S2\} \\
\hline & & & Maximum Limitation: & Bp.N.Sf; Se.S2.Tr \\
\hline
\end{tabular}

Fig 4. Example model output for a given location.

Based on the resulting suitability maps, CONSUS then allows suitable sites to be identified (Figure 5). Sites are regionalized using minimal requirements in terms of suitability (e.g. at least S2) and/or a minimal size of a spatially coherent area (regions A and B in Figure 5a). Note that other coherent areas (grey) of either S1 or S2 are not building regions because they don't reach the size criteria. Sites can also be selected using preexisting administrative boundaries (e.g. countries or districts). In Figure $5 \mathrm{~b}$ regions $\mathrm{C}$ and D are examples of predefined regions (e.g. districts selected for agricultural development). Sites can be further characterized using the region profile (Figure 5c). For each site the relative proportion of all present suitability values gives a first impression. Additional properties include the size of the regions, or indeed zonal statistics for any spatial parameter of the site (e.g. average climatic variables or land use classes).

(a)

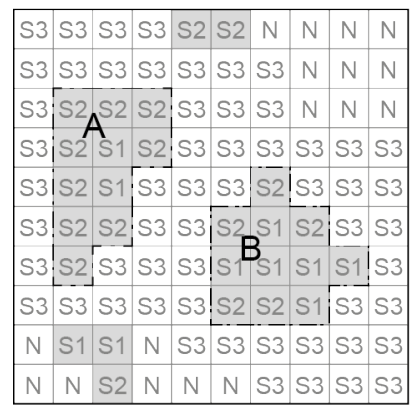

(b)

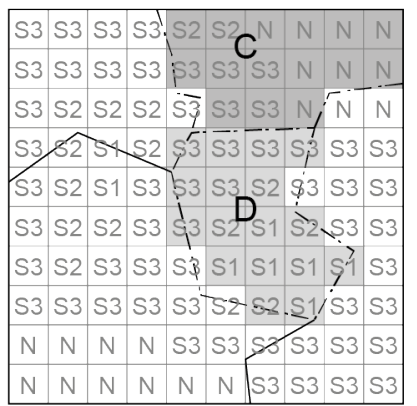

(c)

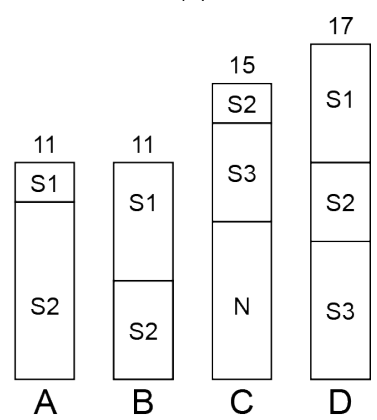

Fig 5. Site selection and site assessment. (a) Regionalization using size and suitability criteria, (b) overlay of predefined regions, e.g. districts, (c) region profiles for $\mathrm{A}, \mathrm{B}, \mathrm{C}$, and $\mathrm{D}$. 


\section{Implementation}

This section gives a brief description of the system architecture and the key technical implementation aspects of the CONSUS suitability evaluation system. CONSUS is structured in three tiers: The data tier, the expert analysis tier, and the decision support tier. The system architecture is modular, connecting database and GIS functionality with data processing scripts in a flexible tool set (Figure 6).

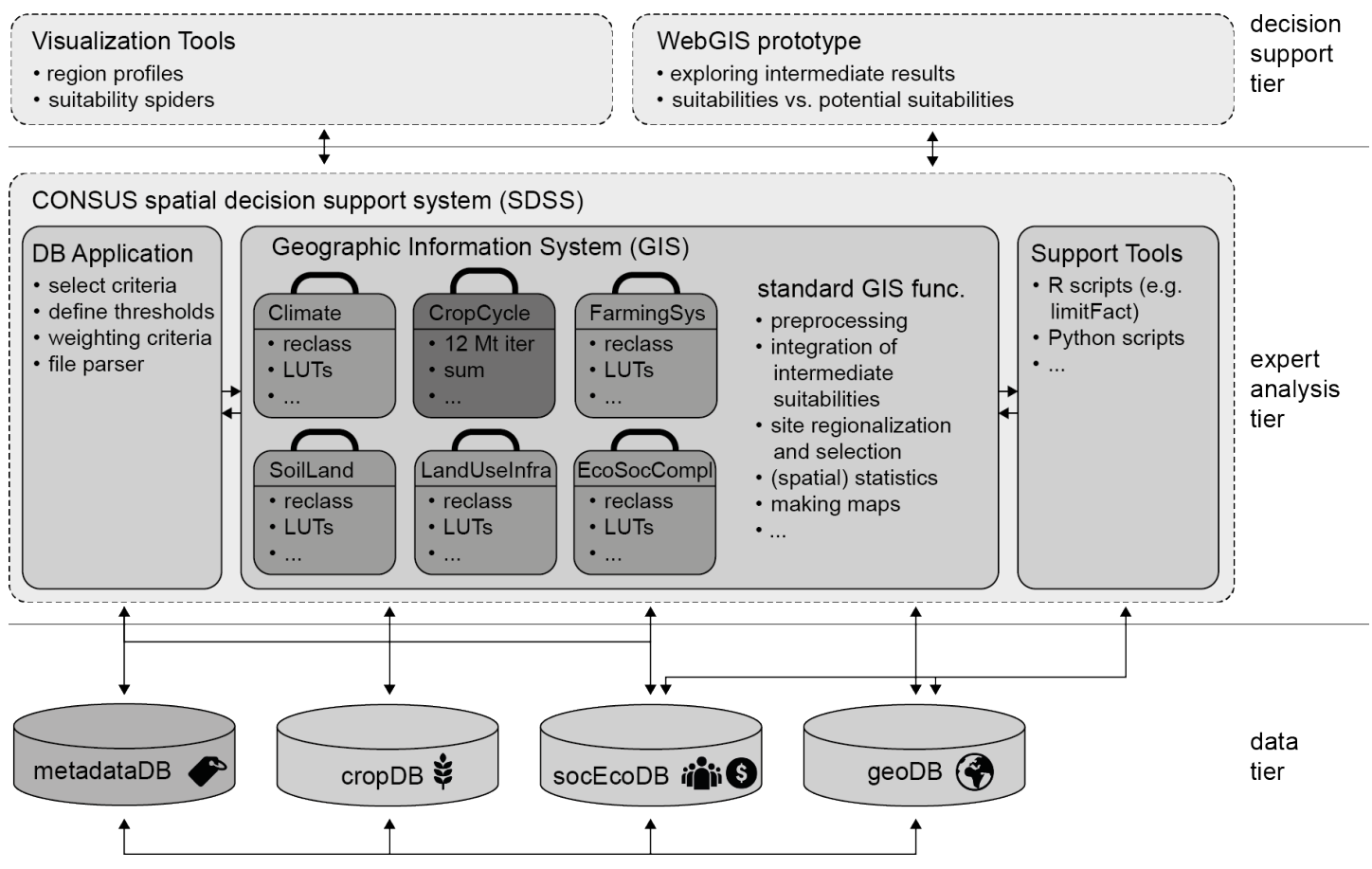

Fig 6. CONSUS system architecture.

The data tier features a set of four loosely connected databases. CONSUS must handle both spatial and nonspatial data. Non-spatial data includes structured data, typically in the form of tables without explicit spatial reference. First, this includes crop requirement information, mainly drawn from specific agricultural literature and expert knowledge. A second important tabular data source includes socio-economic statistics bound to countries or smaller administrative units such as districts or provinces. Although not explicitly spatial in the first place, such data will often come with a spatial reference (e.g. a country, district or other place name), allowing the 'joining' of such attribute data to spatial layers, making it accessible for the CONSUS spatial analysis. Two PostgreSQL relational databases ( $c r o p D B$ and $s o c E c o D B$ ) handle these two key CONSUS knowledge sources. Spatial data includes information on biophysical, socio-economic, and infrastructure conditions within the areas of interest. Spatial data is stored in what is termed here (and in Figures 1 and 5) geoDB for simplicity, but is in fact a structured set of ArcGIS geodatabases containing the respective feature and raster data sets. Finally, a further relational database metadataDB captures and manages metadata characterizing the data used, capturing the data sources, granularities, lineage, quality measures, and potential copyright issues. metadataDB allows keyword-based searches for specific datasets in the CONSUS knowledge base.

The expert analysis tier is a modular tool set combining database management systems (DBMS) with GIS software and scripts for data (pre-)processing and efficient tool integration. Several ArcGIS ModelBuilder toolboxes implement the individual suitability analyses. The $D B$ application provides interfaces for specifying and adapting crop requirements and weighting factors for the multi-criteria evaluation. The DB application furthermore works as an interface between the non-spatial databases ( $\operatorname{cropDB}, \operatorname{socEcoDB}$, metadataDB) and the ArcGIS toolboxes, converting, for example, crop requirements stored in relations into look-up tables (LUTs) readable by the GIS function in the toolboxes.

The actual multi-criteria suitability analysis is implemented through a modular set of connected ArcGIS toolboxes, roughly encapsulating the modules 1 to 5 described in Section 2. The tools Climate and SoilLand calculate the biophysical suitability, LandUseInfra, FarmingSys, and EcoSocCompl assess socio-economic suitabilities. The tool CropCycle implements the optimization approach introduced in Section 2.2 through iteration and subsequent identification of the optimal season for each location. Additional standard GIS functionalities complement the 
toolboxes for preprocessing input data (e.g. harmonization of raster resolutions or coordinate systems), integrating intermediate suitabilities, regionalizing and selecting sites for summative statistics, reporting, and for the production of maps. Selected specific R and Python scripts complete the CONSUS tool set for additional tasks that cannot be covered either by typical DBMS or by standard GIS operations.

The decision support tier finally features applications dedicated to the exploitation of the results generated within the decision making process of the user. In the current CONSUS implementation, this includes visualization tools and a web mapping prototype. The visualization tools graphically encode the characteristics of selected sites as bar charts or suitability spiders. The WebGIS tool offers an interactive display of results in a browser environment.

\section{Proof of concept}

\subsection{Case study 1: Hazelnut}

\subsubsection{Context and Methods}

The goal of the first case study was to identify the most suitable areas for hazelnut (Corylus avellana L.) production in Europe based on biophysical and socio-economic criteria. The case was assessed under the assumption that hazelnuts are to be imported to Switzerland. Currently, $70 \%$ of today's worldwide production takes place in Turkey, mainly because of early entrance into the production and supporting policies. Despite the comparatively very low yields in Turkish production sites, the country has so far managed to keep its leading position in the global market (Kiliç and Alkan, 2006). Given the current strong concentration of hazelnut production in one single region, the supply faces high risks now and in the future. Consequently, the here investigated diversification of production sites aims at increasing the stability of hazelnut supply in the future.

To assess the biophysical suitability, both climate and land \& soil suitabilities were compiled and aggregated. Biophysical requirements of Corylus avellana $\mathrm{L}$. were determined based on various literature sources, including different soil and climate parameters (Table A1, Annex A). Various global data sets were used to perform the suitability assessment. WorldClim data sets were used to assess the climate suitability. The biophysical assessment was based on data sets from HWSD (Harmonized World Soil Database) and Esri Terrain service.

For the socio-economic suitability, module 5 was applied in order to evaluate business and compliance suitability. As shown in Table A2, Annex A, recognized global indices were assigned to different suitability classes. Business indices regarding ease of business and costs were supplemented by import taxes for hazelnuts to Switzerland. Note, whereas for the biophysical suitability the thresholds for the suitability classes S1, S2, S3, and N are directly drawn from the literature, for the socio-economic suitability the setting of the used thresholds, and hence the reclassification into suitability classes, was done by the CONSUS experts interpreting related work discussing socio-economic suitability aspects in the given context. Compliance indices concern governance and risks of unfair treatment of laborers.

As a further established European hazelnut producer, Italy was chosen for an illustration of the CONSUS regionalization procedure. Given that in the hazelnut case study no socio-economic information beyond country level was used, the regionalization procedure was limited to the fine-grained biophysical suitability. To this end, only S1 and S2 areas were considered and aggregated. The aggregation criteria applied include an aggregation distance of $5 \mathrm{~km}$ (areas less than $5 \mathrm{~km}$ apart were merged) and a minimum area of $10 \mathrm{~km}^{2}$ (smaller areas were eliminated).

\subsubsection{Results}

The calculated biophysical suitability for hazelnuts in Europe (modules 1 and 2) reveals respectable S2 and S3 belts, mainly in the warm-temperate zones of Northern and Central Europe (France, Germany, but also Ireland, Belgium, The Netherlands, and Denmark), as well as towards the warmer zones in Southern Europe (Italy, Greece, Croatia, Serbia, Bosnia and Herzegovina, and Slovenia: see Figure 7). The most limiting factor here is precipitation, notably towards the south rainfall is simply too scarce for the cultivation of hazelnuts. A further limiting factor comes with low temperatures in mountainous areas (as in the Pyrenees or the Alps) and when heading further north. Within the area of Central Europe depicted the precipitation and temperature requirements are mutually exclusive for wide areas, hence S1 is practically absent. In Europe, the soil characteristics are much more limiting than the climatic characteristics. Key limiting requirements are soil depth and soil fertility $(\mathrm{pH})$. Soil texture adds further limitations and in mountainous areas steeper slopes act as an additional limitation. Overall, it has to be stated that the lack of S1 clearly follows from the nature of the maximum limitation method, in which the overall outcome is always determined by the worst parameter. It is therefore unlikely that overall suitabilities of S1 can be achieved as this would require all the contributing parameters to be highly suitable (S1). 


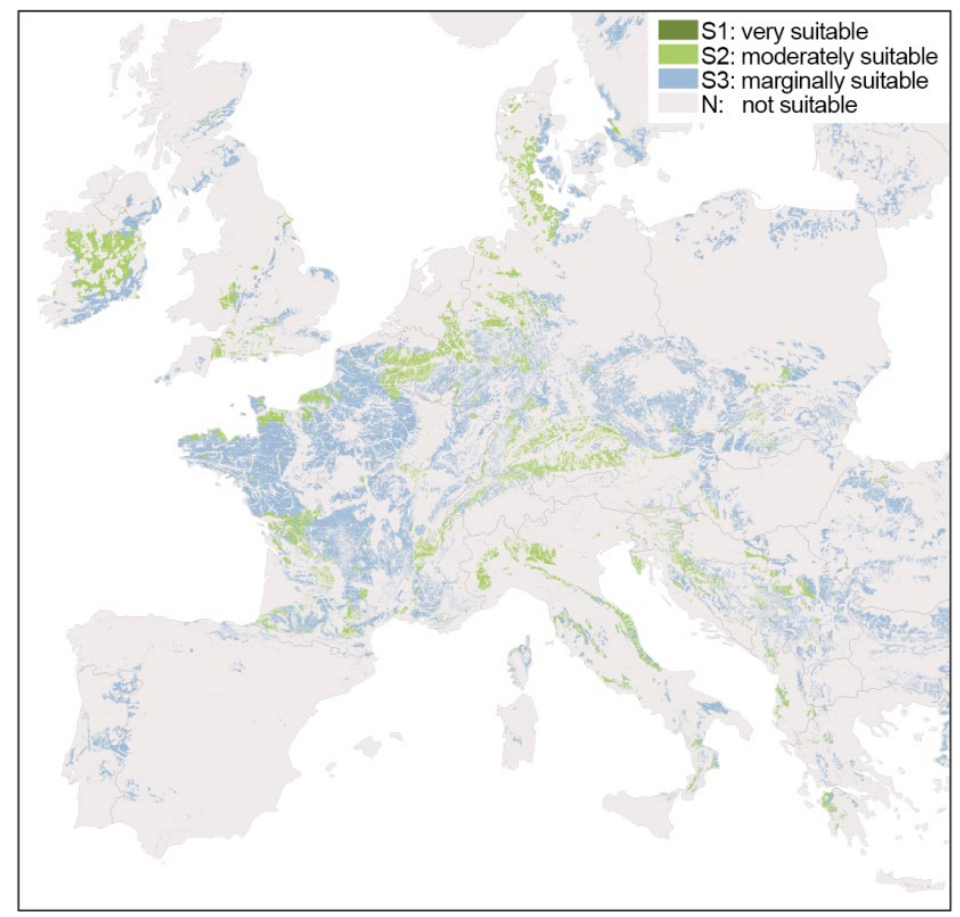

Fig 7. Calculated biophysical suitability for hazelnuts for Europe (Modules 1 and 2)

Business suitability and compliance suitability (module 5) show to a large degree contrasting spatial patterns (see Figure 8). Most countries in central Europe show high compliance suitabilities but lower business suitabilities, the latter mainly following relatively high labor costs (e.g. Central Europe, United Kingdom, Norway). Countries in Southeast Europe show high S1 and S2 values for business suitability, but in contrast lower compliance suitabilities ( $\mathrm{S} 2$ and $\mathrm{S} 3$ ). Here, business suitability is high given the comparatively low labor costs. Some limitations arise from import tariffs for Balkan states that are not part of the European Union. By contrast, some countries in Southeast Europe show some limitations regarding compliance suitability due to social risks such as child labor or forced labor (in Albania, Bosnia and Herzegovina, and Montenegro) as well as concerns regarding political instability (Ukraine, Russia). In sum, within Europe, overall business and compliance suitability is not a limiting factor and the class $\mathrm{N}$ is not to be found (with the exception of Norway with its high labor costs).

(b)

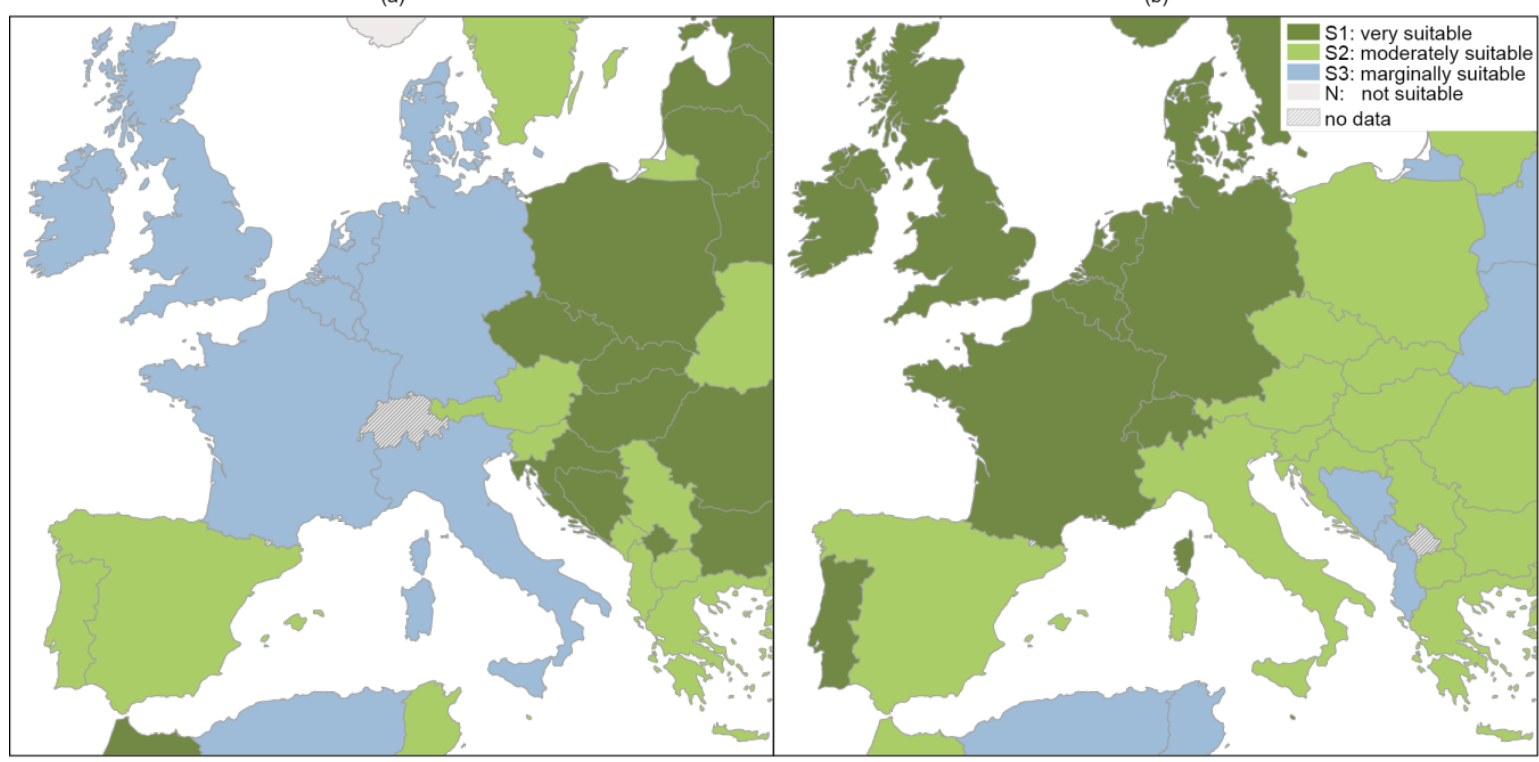

Fig 8. Business suitability (a) and compliance suitability (b) for hazelnuts in Europe (Module 5).

The six largest suitable zones in Italy are depicted in Figure 9. Regionalization of the overall suitability reproduced the expected major growing areas in the Piedmont and Lombardy regions, but also revealed a coherent suitable 
belt along the Adriatic coast. Although high suitability for a given crop does not necessarily mean that this crop is indeed cultivated, the fact that CONSUS identified the current major hazelnut production areas in Italy may serve as a preliminary validation of our model.

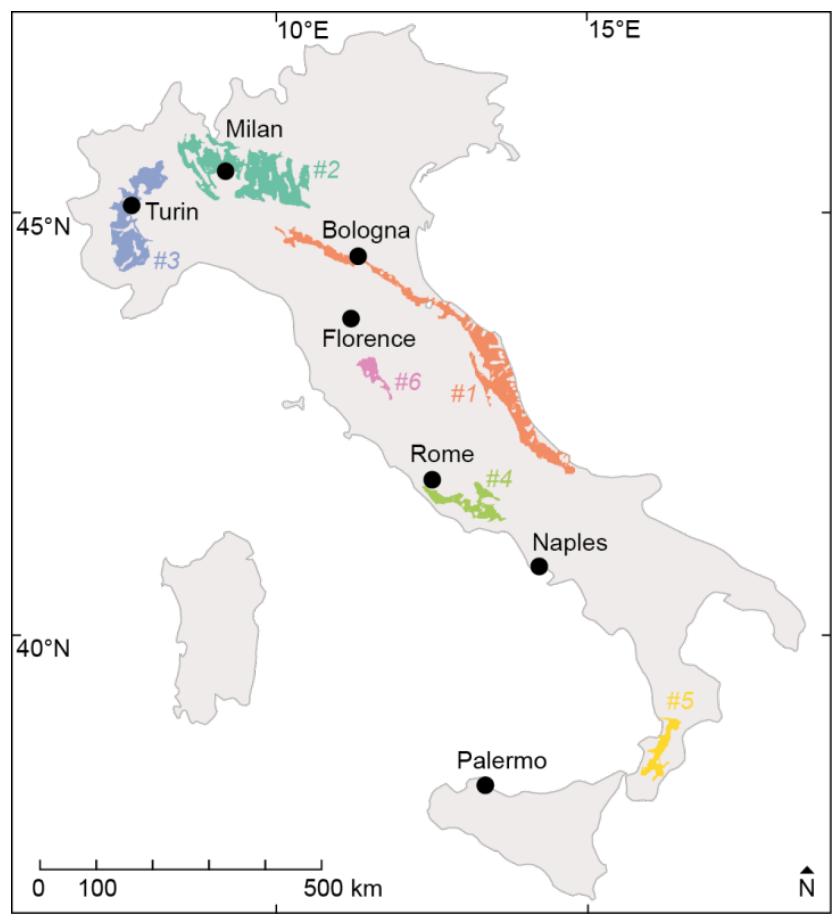

Fig 9. Biophysical suitability for hazelnuts - six largest suitable areas in Italy: \#1 Eastern Apennines, $13400 \mathrm{~km}^{2}$; \#2 Lombardy, $12500 \mathrm{~km}$; \#3 Piedmont, $7200 \mathrm{~km}^{2}$; \#4 Lazio $3000 \mathrm{~km}^{2}$; \#5 Calabria, $2150 \mathrm{~km}^{2}$; \#6 Tuscany, $1250 \mathrm{~km}^{2}$.

\subsection{Case Study 2: Rwanda}

\subsubsection{Context and Methods}

To illustrate CONSUS on a regional scale, the suitability of soybeans was assessed for Rwanda as a second case study. The change of scale and the resulting different nature of input data required the application of a different combination of modules (see Fig. 1). For this regional application of CONSUS, modules 1, 2, 3 and 4 were used.

The biophysical crop requirements of soybean were determined based on literature (Table B1, Annex B). In addition to the data used in case study 1, the suitability assessment was based on data sets from CliMond, SRTM, ASTER GDEM and LADA Land Use. The Rwanda case study furthermore illustrates the use of the CONSUS crop cycle optimizer (see Figure 3). Here, the tool was used to optimize the climatic suitability, allowing for a temporal shift of the start of the growing season. In addition to the current suitability, potential suitability for soybean production in Rwanda was assessed. Factors which are potentially adjustable through soil improvement measures are not included in this assessment. Based on Verdoodt and Van Ranst (2003), these include the cationexchange capacity (CEC) of the soil, drainage, organic matter, $\mathrm{pH}$ and base saturation. To account for improvement of the slope through terracing, the requirements for slope are adjusted as follows: only slopes $>55$ $\%$ or slopes $>25 \%$ with a soil depth of $<50 \mathrm{~cm}$ are classified as unsuitable. In all other cases, slope requirements are not included.

The socio-economic land evaluation in the Rwanda case study comprises a farming system evaluation on the regional level (module 4). The evaluation builds on site characteristics chosen according to the list of factors defining an agricultural land utilization type (FAO, 1985; see Table 1). Factors are included in the socio-economic evaluation based on their importance regarding soybean production, on data availability in Rwanda and on the variance between the spatial units analyzed.

Again, whereas the biophysical niche description above is directly derived from the literature, the subsequent socio-economic niche description required the CONSUS experts' interpretation of related sources and subsequent reclassification of factors into suitability values. Based on the assumption that it is easier to source soybean from 
a region where a certain number of farmers are already producing larger shares for the market instead of for household consumption, the percentage of overall harvest sold in a district is included in the farming system evaluation. In addition, following the arguments that soybean production is more efficient in larger production areas (Mugabo et al., 2014) and that farms smaller than 0.72 ha do not produce enough surpluses to sell their crops on the market (Mujawamariya, 2012), a district's percentage of households cultivating more than 0.9 ha is incorporated as a site characteristic in the farming system evaluation. Moreover, it is expected that it is easier to source soybean from a region where a certain amount of soybean is already produced. Thus, the percentage of households in a district producing soybean is included as well. Since fertilizers are an important factor contributing to the efficiency of soy production (Mugabo et al., 2014), the percentage of a district's household expenditure on fertilizers is likewise integrated into the evaluation. The site characteristics included were reclassified into four suitability classes and then aggregated into a single value per district (see Table B2, Annex B).

\subsubsection{Results}

The biophysical suitability for soybeans is rather low for the entire country, apart from very few S2 spots in the southwest (Figure 10a). The entire remainder of the country is not suitable $(\mathrm{N})$ or only marginally suitable $(\mathrm{S} 3)$. From studying the individual contributing factors, it becomes evident that the most limiting factor here is the CEC and the base saturation. Climate and slope additionally diminish the suitability for cultivation, especially in the western and northern provinces. In the eastern part, several areas are excluded because of the natural vegetation coverage. Figure 10c illustrates the effect of the crop cycle optimizer for climatic suitability alone. The map depicts the climatic suitability in October as the starting month for the growing season with the areas that are improved by the application of the crop cycle optimizer. The dark blue (S3) and the dark green (S2) areas are additional S3 and S2 cells resulting from the application of the crop cycle optimizer. Although for soybeans in Rwanda the overall effect of the crop cycle optimizer is moderate, the new contiguous S2 (dark green) area in the north east and some additional S3 cell bands (dark blue) extending the western S3 areas illustrate its effect.

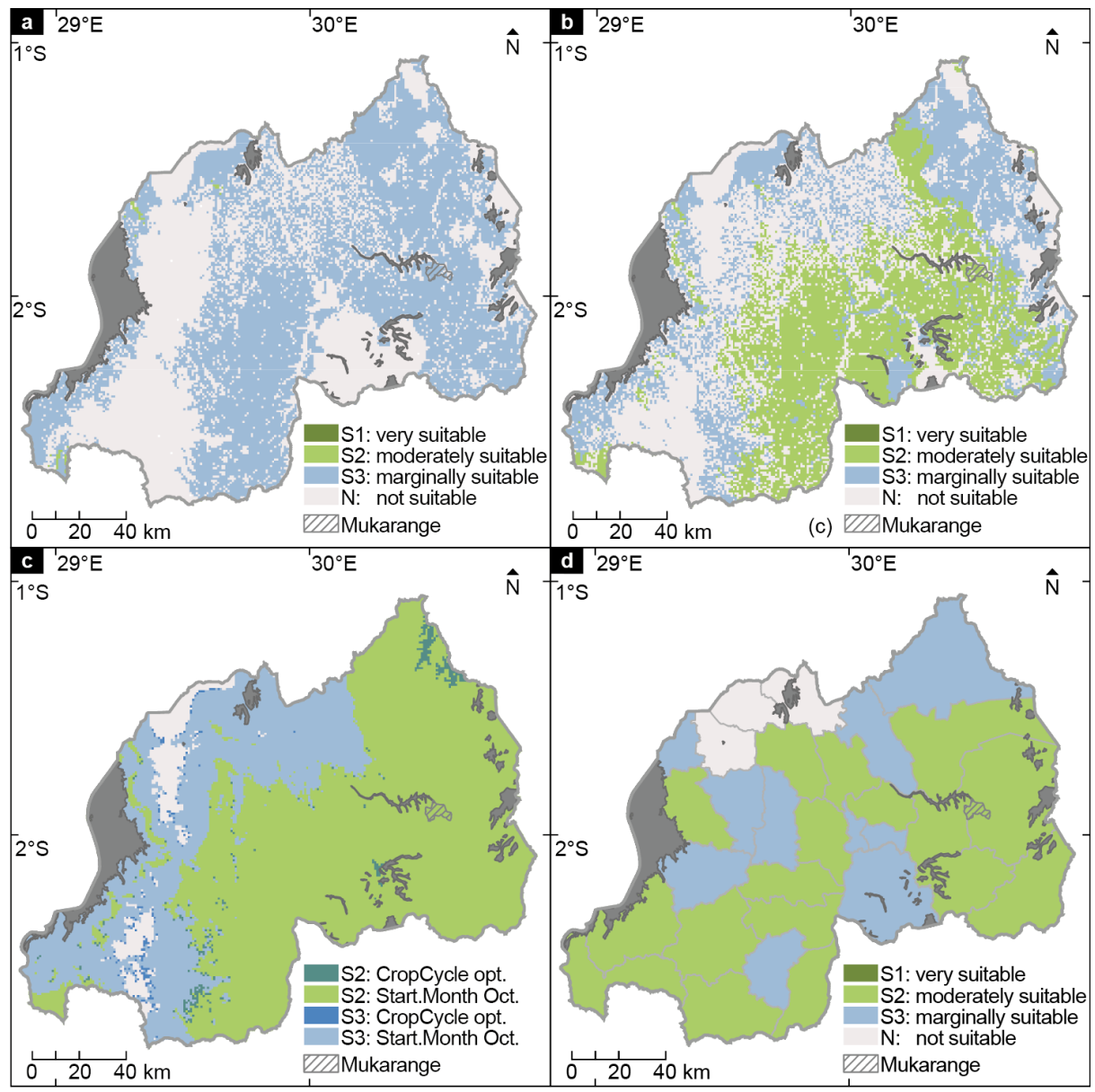

Fig 10. Suitability for soybean cultivation in Rwanda. (a) overall suitability, (b) potential suitability, (c) climatic suitability for October as starting month of the growing season compared to the result of the crop cycle optimizer, (d) farming system suitability, water bodies in grey. 
The importance of the limiting factors becomes even more evident in Figure 10b, which illustrates the potential suitability when a set of limiting factors was improved. In this example the manageable soil parameters (drainage, organic carbon, $\mathrm{pH}$, base saturation, CEC, slope) were excluded. As already discussed in Section 4.2.1 slope was not simply removed from the equation but adjusted following the approach described in Verdoodt and Ranst (2003). After the improvement, the potential suitability map features many more suitable areas (S2), especially in Southeast Rwanda (provinces Sud and Est).

The map in Figure 10d depicts the results of module 4 - farming system suitability. There is a moderate trend towards higher farming system suitabilities towards the South. A closer look at the individual contributing factors reveals that, in general, Rwandan agriculture is based on small farms that produce on a low level for the market, and already cultivate soybeans, but in small quantities. Only three districts are not suitable with respect to their farming system $(\mathrm{N})$. This result is caused by their current low production of soybean $(0.6 \%$ or less of a district's households are producing soybeans). As a general observation, also here the nature of the maximum limitation method becomes evident; achieving S1 overall suitabilities is difficult as this requires all parameters to be in the S1-class.

Finally, three specific districts were further investigated using the CONSUS profile functionality (Figure 11). In contrast to case study 1: Hazelnuts, where coherent suitable sites were first created using the CONSUS regionalization procedure, here pre-existing regions (aka political districts) were used for profiling. The three selected districts were Kayonza (location of the biggest soybean processing plant in Rwanda, Mukarange, see Figure 10c), Muhanga (most significant household production of soybeans to date), and Rwamagana (most suitable district, three times S1 and once S2). The profiles reveal the limiting factors for the different regions. Whereas CEC is the most limiting factor in all three districts, limitations from other factors vary between the districts. Land cover, for example, is strongly limiting soybean production in Kayonza but not in Muhanga and only slightly limiting in Rwamagana. These illustrations also help identify required soil management practices.

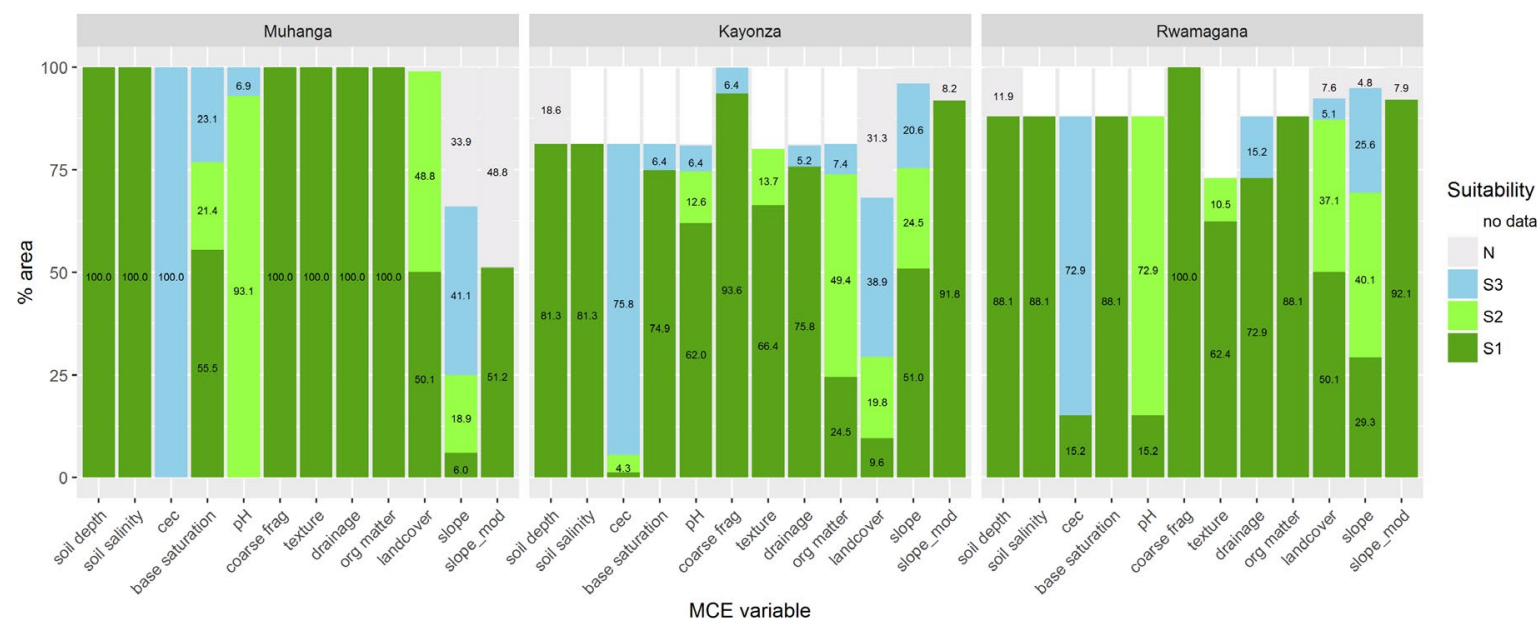

Fig 11. Region profiles for module 2: Soil \& land suitability. Note that for some parameters the input data does not cover the entire perimeter, resulting in 'no data' values for the respective pixels.

\section{Discussion}

This section first reflects on the CONSUS model and its implementation in the light of the case study validation, and secondly discusses our proposed approach with respect to recent related research.

The modular architecture of CONSUS proved very useful for a flexible and efficient application of the CONSUS model to a rather wide range of application scenarios, as illustrated with the two case studies. This applies first and foremost to our goal of providing a multi-scale solution, as adapting the scale of the CONSUS only requires selecting a slightly different set of modules (modules 1,2,3, and 4 for the regional scale, 1,2,3, and 5 for the global scale). Whereas both our case studies predominantly used global data sets, where more detailed data is available for larger scales, it can easily be integrated into CONSUS. Although the mechanics and hence the output format of the modules may vary from scale to scale, the integrative functionality of the GIS/database core allows intermediate suitabilities to be fused into a holistic result - irrespective of the scales or data formats of heterogeneous multi-source input data. The explicit CONSUS goal of extending the classic land evaluation frameworks to include socio-economic suitability and compliance perspectives meant accommodating even more diverse and heterogeneous data than in a conventional regional suitability study focusing mainly on the biophysical perspective. 
The advantage of the maximum limitation method is that it is easy to understand, easy to communicate to clients and users, and finally easy to implement. However, in both case studies the maximum limitation method clearly confirmed its well-known and often debated restrictive nature, as achieving S1 for any location does not tolerate a single inferior rating and is consequently rather unlikely. In addition, the more parameters, the more restrictive is the maximum limitation method; considering both biophysical and socio-economic aspects CONSUS can reach up to 30 parameters. Some recent GIS-based land suitability studies have used concepts related to fuzzy set theory for combining individual criteria as a more sophisticated alternative to the maximum limitation method used in CONSUS (e.g. Zhang et al. (2015) for tabacco in China). Fuzzy set theory can add an important notion of vagueness to otherwise all too often rather definite and deterministic suitability models. However, the consequent integration of fuzzy set theory into land suitability analysis rapidly increases the complexity of the reasoning, especially for models with a broad perspective including multiple and diverse criteria such as CONSUS. This not only complicates the implementation of the suitability models, but also makes communication of the analytical reasoning and its results much harder, and hence hampers the inclusion of multi-criteria analysis into the decision making process. For this reason the CONSUS model does not include fuzzy concepts, but combines both biophysical and socio-economic parameters with the more straightforward maximum limitation method while fully acknowledging the known limitations of this approach.

Both our case studies concur that data availability and access to the necessary information for the definition of suitability classes is better for the biophysical aspects and more difficult for the socio-economic aspects, both on the local and the global scale. Furthermore, biophysical data is often available at much finer granularities than socio-economic data. This was especially evident in the Rwanda case study, where fine-grained raster data on local biophysical characteristics ( $1 \mathrm{~km}$ cell size) had to be merged with much coarser district-based farming system data. However, raster granularity should not be confused with spatial accuracy or precision, as, for example, seemingly very fine-grained local temperature data is not measured in such a fine-grained resolution, but is only derived from a coarse global climate model. Furthermore, any integration of geodata from multiple and heterogeneous sources requires careful consideration of the various data qualities and uncertainties, as poor quality input data may propagate through the analysis process. Although data quality issues were not systematically addressed in our case studies, the limitations of input data and their implications for the analysis process were discussed with the decision makers in the case studies. Finally, regarding data availability, our two case studies concur with Elsheikh et al.(2013) in that the data availability has a significant impact on the selection of the parameters for the suitability assessment, and hence presents a potential source of bias.

Moreover, both our case studies illustrate that an all-inclusive perspective (biophysical \& socio-economic) is paramount for delivering the comprehensive suitability assessment requested by clients, as often biophysically highly suitable areas are eventually downgraded for socio-economic reasons (e.g., high labor costs for hazelnut production in Italy, Germany, or France). However, combining the comprehensive perspective with the aforementioned rather restrictive nature of the maximum limitation method can easily lead to overly conservative assessments of overall suitability.

Both case studies showed that a more differentiated review of intermediate suitabilities, studying potential suitabilities and allowing for a sensible adaptation of requirements, were more useful to the clients than strict overall assessments. The case study Rwanda illustrated the successful application of potential biophysical suitability. Whereas with the strict MLM almost the entire study area expressed low S3 and N suitabilities, allowing for a directed amelioration of the most limiting factors enabled a more positive picture featuring extended $\mathrm{S} 2$ areas to emerge. Similar compensations are possible for socio-economic suitability, although the interrelations are more complex. By improving business and compliance suitability, a company could undertake special efforts to avoid certain social risks, although this would involve higher production costs. Alternatively, farming practices could be changed by a sourcing project by providing material, technological and educational support, and market access to improve the suitability of the farming system. Further, farming system suitability as well as business and compliance suitability is interrelated with the modification of biophysical parameters. For example, if biophysical parameters can be adapted at low cost, lower biophysical suitabilities can be acceptable for a certain production site (e.g. changing soil properties at low labor costs). However, low costs are often linked to increased social risks that in turn also lower the overall suitability of the area. Overall, the socio-economic requirements are less strict: they indicate where it would be easier, considering socio-economic circumstances, to start producing or sourcing a certain crop, but they do not strictly exclude regions as 'socio-economically not suitable'.

The hazelnut case study revealed that up-scaling from a local to a regional or even a global scale requires the inclusion of seasonality, as the temporal extent of optimal crop cycles is expected to change across climate zones. The subsequently developed crop cycle optimizer, only applied in our second case study, Rwanda, successfully allowed for the inclusion of such seasonality (as illustrated in Figure 10c). However, for the overall suitability the 
crop cycle optimizer had little effect, as optimized climatic suitabilities where subsequently overruled by lower land \& soil suitabilities.

A further lesson was learnt by comparing the global with the regional/local case studies. Changing scales may mean that the very same variable (e.g., precipitation or current land use) can come from rather different methods or sources. This can be very evident for socio-economic suitability, which uses very different data for the global or regional/local scales (as data resolution is bound to administrative units, on each scale showing different data from rather different sources).But also the data quality of biophysical parameters may vary with scale. Whereas in regional/local studies CONSUS might have access to fine-grained precipitation data from the dense sensor network of a national meteorological office, a global case study may be restricted to modelled rather than measured precipitation data with much lower quality. In short, changing scales typically means changing data sources, requiring a careful re-evaluation of the qualities of the data used.

CONSUS complements a set of recent technology-driven advancements and modifications of the FAO framework model, all illustrating the huge potential of integrating GIS-based multi-criteria evaluation with recent information technologies. Whereas CONSUS explored a tight integration of GIS with recent database technologies, Elsheikh et al., (2013) combine GIS MCE with a participatory expert system and Zolekar and Bhagat, (2015) with remote sensing procedures. However, both these studies focus on biophysical 'geo-environmental factors', whereas CONSUS strives for the additional inclusion of the socio-economic dimension. The inclusion of even wider and more heterogeneous data sources for this purpose required a much tighter database integration in our case, exemplified in the design and implementation of the interfaces between our GIS and the $\operatorname{cropDB}$ and $\operatorname{soc} E \operatorname{coDB}$.

Similarly to other related studies, also CONSUS confirms the importance of offering intermediate suitability maps (e.g., Zolekar and Bhagat, 2015) and the use of potential suitability maps (e.g., Akinci et al., 2013). But again, both these studies focus on biophysical parameters alone. CONSUS furthermore extends suitability maps with decision support tools moving beyond mere maps, including regionalization of suitable sites and derived country or site profiles. This is especially important, since both our case studies showed that the presentation of overall suitabilities in the form of a static suitability map (as, for example, in Fig 10, the Rwanda map) is only the beginning of a serious suitability study. At the same time, the inclusive and wide focus of a tool like CONSUS can easily lead to an over-abundance of information, overburdening the typical user with too much detail. Hence, overview and detail on demand need to be carefully balanced. The CONSUS regionalization procedure offers a tool for generalizing suitable areas, highlighting only the largest suitable sites per country. Whereas in some decision situations this may be exactly the generalization required, in others one may want to focus on the many very small but potentially highly suitable sites scattered over larger areas.

Whether in the CONSUS team or in discussions with clients, only the detailed investigation of the intermediate suitabilities, each contributing with a specific spatial pattern to the overall suitability, together with further information visualizations (country profiles) led to a deeper understanding of the diverse geographic processes resulting in the overall suitability.

\section{Conclusions}

CONSUS is based on the FAO multi-criteria land evaluation framework but extends it with key contributions in three dimensions. First and foremost CONSUS reaches out beyond biophysical suitability alone and integrates environmental, economic, and social suitability factors. Secondly, it considers the entire value chain, including additional upstream activities relevant for product trading. And thirdly, CONSUS moves beyond static analysis time-stamps and introduces an adaptive crop cycle model allowing for spatio-temporal variation of the optimal cropping period within a study area. Implementation-wise CONSUS tightly integrates a modular set of ArcGIS ModelBuilder tools with several relational databases that serve as a knowledge base for crop requirements and socio-economic characteristics of the study areas. The decision process is further supported, beyond mere suitability maps, by functionality to assess potential suitability, specifically modifying the most limiting factors, and to delineate and visually characterize potential sites with site/country profiles. The model and its implementation have been successfully applied and put to the test in two case studies, one for hazelnuts on a global scale and one for soybean on a local scale.

CONSUS has been found to be a useful tool for the identification of suitable production sites and for the identification of major limitations for production and sourcing. These applications offer important insights relevant to decision-makers in policy, non-governmental organizations, and in the private agrofood sector. From the demand-side perspective, CONSUS can support businesses with knowledge regarding site selection and investment decisions, and thus help reduce costs and risks in new direct sourcing projects. The overall feasibility, 
limitations and potentials of such intentions can be assessed. From the supply-side perspective, the results can contribute to and offer insights into new production opportunities and help reduce the risks of such investments. Governmental authorities, producers' organizations and other non-governmental organizations can benefit from the opportunity to assess the overall suitabilities of new crops, and use results for extension services, regional planning and strategic development plans. CONSUS can also be applied for further research; especially in the context of climate change, various questions arise which can readily be addressed e.g. shift of crop production areas or identification of alternative drought-resistant crops.

Future work focuses on several extensions of the CONSUS model and framework. A key conceptual extension is the relaxation of the maximum limitation rationale. Given the breadth and diversity of parameters that need to be considered for the holistic perspective central to CONSUS, the application of more complex and flexible aggregation metrics than MLM will be tested and evaluated in case studies. Implementation-wise a batch-import interface to simplify importing and updating large volumes of structured socio-economic data will be realized. In addition, a webGIS version of CONSUS is in development, bringing the decision-support process much closer to the client through web access to data and interactivity. Finally, several additional case studies are lined up that will further consolidate the CONSUS model and its implementation (e.g., avocados in Guatemala, quinoa in Europe, underutilized crops in Africa).

\section{Acknowledgements}

The CONSUS project was funded by the Syngenta Foundation for Sustainable Agriculture (SFSA). The authors express their special gratitude to Dr. Dominik Klauser and Dr. Michael Robinson for their valuable inputs and contributions whilst accompanying the project for SFSA.

\section{References}

Akinci, H., Özalp, A.Y., Turgut, B., 2013. Agricultural land use suitability analysis using GIS and AHP technique. Comput. Electron. Agric. 97, 71-82. doi:10.1016/j.compag.2013.07.006

Alabi, T., Sonder, K., Oduwole, O., Okafor, C., 2012. A Multi-criteria GIS site selection for sustainable cocoa development in West Africa: A case study of Nigeria. Int. J. Appl. Geospatial Res. 3, 73-87. doi:10.4018/jagr.2012010107

Ayorinde, K., Lawal, R.M., Muibi, K., 2015. Land Suitability Assessment for Cocoa Cultivation in Ife Central Local Government Area, Osun State. Int. J. Sci. Eng. Res. 3, 139-144.

Carver, S., 1991. Integrating multi-criteria evaluation with geographical information systems. Int. J. Geogr. Inf. Syst. 5, 321339. doi:10.1080/02693799108927858

Chen, Y., Yu, J., Khan, S., 2010. Spatial sensitivity analysis of multi-criteria weights in GIS-based land suitability evaluation. Environ. Model. Softw. 25, 1582-1591. doi:10.1016/j.envsoft.2010.06.001

Dal Belo Leite, J.G., Justino, F.B., Silva, J.V., Florin, M.J., van Ittersum, M.K., 2015. Socioeconomic and environmental assessment of biodiesel crops on family farming systems in Brazil. Agric. Syst. 133, 22-34. doi:10.1016/j.agsy.2014.10.005

de la Rosa, D., van Diepen, C.A., 2002. Qualitative and Quantitative Land Evaluation, in: Encyclopedia of Life Support System (EOLSS-UNESCO). Eolss Publishers, Oxford, UK.

Elsheikh, R., Mohamed Shariff, A.R.B., Amiri, F., Ahmad, N.B., Balasundram, S.K., Soom, M.A.M., 2013. Agriculture Land Suitability Evaluator (ALSE): A decision and planning support tool for tropical and subtropical crops. Comput. Electron. Agric. 93, 98-110. doi:10.1016/j.compag.2013.02.003

FAO, 2007. Land Evaluation. Towards a revised framework (No. 6), Land and water Discussion Paper. Rome.

FAO, 1985. Guidelines: land evaluation for irrigated agriculture, FAO soils bulletin. FAO, Rome.

FAO, 1976. A framework for land evaluation, in: FAO Soils Bulletin 32. p. 87.

He, Y., Liu, D., Yao, Y., Huang, Q., Li, J., Chen, Y., Shi, S., Wan, L., Yu, S., Wang, D., 2013. Spatializing growth suitability for spring soybean cultivation in northeast China. J. Appl. Meteorol. Climatol. 52, 773-783. doi:10.1175/JAMC-D-11-0259.1

Heumann, B.W., Walsh, S.J., Verdery, A.M., McDaniel, P.M., Rindfuss, R.R., 2013. Land Suitability Modeling using a Geographic Socio-Environmental Niche-Based Approach: A Case Study from Northeastern Thailand. Ann. Assoc. Am. Geogr. 103, 37-41. doi:10.1080/00045608.2012.702479 
Kiliç, O., Alkan, I., 2006. The developments in the World Hazelnut Production and Export, the role of Turkey. J. Appl. Sci. doi:10.3923/jas.2006.1612.1616

Longley, P., Goodchild, M., Maguire, D., Rhind, D., 2011. Geographic information system and Science, 3rd ed. John Wiley \& Sons Ltd., Chichester, England.

Malczewski, J., 2006. GIS-based multicriteria decision analysis: a survey of the literature. Int. J. Geogr. Inf. 20, 703-726. doi:10.1080/13658810600661508

Malczewski, J., 1999. GIS and multicriteria decision analysis. John Wiley \& Sons Ltd., New York.

Mandryk, M., Doelman, J., Stehfest, E., 2015. Assessment of global land availability: land supply for agriculture, FOODSECURE Technical paper.

Mendas, A., Delali, A., 2012. Integration of MultiCriteria Decision Analysis in GIS to develop land suitability for agriculture: Application to durum wheat cultivation in the region of Mleta in Algeria. Comput. Electron. Agric. 83, 117-126. doi:10.1016/j.compag.2012.02.003

Mugabo, J., Tollens, E., Chianu, J., Obi, A., Vanlauwe, B., 2014. Resource Use Efficiency in Soybean Production in Rwanda 5, 116-122.

Mujawamariya, M., 2012. Identification of Potential Niches for Soybean cultivation in Farming systems of Eastern and Southern Rwanda. Wageningen University.

Nijbroek, R.P., Andelman, S.J., 2015. Regional suitability for agricultural intensification: a spatial analysis of the Southern Agricultural Growth Corridor of Tanzania. Int. J. Agric. Sustain. 5903, 1-17. doi:10.1080/14735903.2015.1071548

Ojiem, J.O., De Ridder, N., Vanaluwe, B., Giller, K.E., 2006. Socio-ecological niche : a conceptual framework for integration of legumes in smallholder farming systems. Int. J. Agric. Sustain. 4, 79-93. doi:10.1080/14735903.2006.9686011

Pretty, J., 2008. Agricultural sustainability: concepts, principles and evidence. Philos. Trans. R. Soc. Lond. B. Biol. Sci. 363 , 447-65. doi:10.1098/rstb.2007.2163

Qiu, F., Chastain, B., Zhou, Y., Zhang, C., Sridharan, H., 2014. Modeling land suitability/capability using fuzzy evaluation. GeoJournal 79, 167-182. doi:10.1007/s10708-013-9503-0

Rossiter, D., 1996. A theoretical framework for land evaluation. Geoderma 72, 165-190. doi:10.1016/0016-7061(96)000316

Sharififar, A., Ghorbani, H., Sarmadian, F., 2016. Soil suitability evaluation for crop selection using fuzzy sets methodology. Acta Agric. Slov. 107, 159-174. doi:10.14720/aas.2016.107.1.16

Sys, C., Van Ranst, E., Debaveye, J., 1991. Principles in land evaluation and crop production calculationsuation and crop production calculations, in: Land Evaluation. Part I. Agricultural Publications Nº , Brussels, Belgium. doi:10.1097/00010694-197006000-00011

Verdoodt, A., Van Ranst, E., 2006. Environmental assessment tools for multi-scale land resources information systems: A case study of Rwanda. Agric. Ecosyst. Environ. 114, 170-184. doi:10.1016/j.agee.2005.10.006

Verdoodt, A., Van Ranst, E., 2003. Land Evaluation for Agricultural Production in the Tropics. A Two-Level Crop Growth Model for Annual Crops. Ghent University, Ghent.

Worboys, M., Duckham, M., 2004. GIS: a computing perspective, 2nd ed. CRC Press LLC, Boca Raton, Florida.

Zhang, J., Su, Y., Wu, J., Liang, H., 2015. GIS based land suitability assessment for tobacco production using AHP and fuzzy set in Shandong province of China. Comput. Electron. Agric. 114, 202-211. doi:10.1016/j.compag.2015.04.004

Zolekar, R., Bhagat, V., 2015. Multi-criteria land suitability analysis for agriculture in hilly zone: Remote sensing and GIS approach. Comput. Electron. Agric. 118, 300-321. doi:10.1016/j.compag.2015.09.016

ANNEX A. Requirements of Corylus avellana $L$. 
Table A2: Biophysical requirements of Corylus avellana L. (adapted from (FAO - Food and Agriculture Organization of the UN, 2007; Kidd et al., 2015; Malone et al., 2015; Olsen, 2013; Sarioglo et al., 2013; Snare, 2006; Ustaoğlu, 2012)

\begin{tabular}{|c|c|c|c|c|c|}
\hline Criteria & Data source & S1 & S2 & S3 & $\mathbf{N}$ \\
\hline \multicolumn{6}{|l|}{ Climate } \\
\hline $\begin{array}{l}\text { Mean annual } \\
\text { precipitation }(\mathrm{mm})\end{array}$ & $\begin{array}{l}\text { WorldClim - Global Climate } \\
\text { Data (2016) } \\
\text { (BIO12) }\end{array}$ & $>800$ & $700-800$ & $600-700$ & $<600$ \\
\hline $\begin{array}{l}\text { Mean annual temp. } \\
\left({ }^{\circ} \mathrm{C}\right)\end{array}$ & $\begin{array}{l}\text { WorldClim - Global Climate } \\
\text { Data (2016) (BIO1) }\end{array}$ & $13-16$ & $16-19$ or $6-13$ & $-1-$ & $>19$ or $<6$ \\
\hline $\begin{array}{l}\text { Max. temp in } \\
\text { warmest month }\left({ }^{\circ} \mathrm{C}\right)\end{array}$ & $\begin{array}{l}\text { WorldClim - Global Climate } \\
\text { Data (2016) (BIO5) }\end{array}$ & $20-30$ & $30-33$ or $18-20$ & $33-37$ & $>37$ or $<18$ \\
\hline $\begin{array}{l}\text { Min. temp. in } \\
\text { coldest month in } \\
\left({ }^{\circ} \mathrm{C}\right)\end{array}$ & $\begin{array}{l}\text { WorldClim - Global Climate } \\
\text { Data (2016) (BIO6) }\end{array}$ & $>-5$ & -5 to -8 & -8 to -10 & $>-10$ \\
\hline $\begin{array}{l}\text { Chill Hours (h with } \\
0^{\circ} \mathrm{C}-7^{\circ} \mathrm{C} \text { per year) }\end{array}$ & $\begin{array}{l}\text { Derived from WorldClim - } \\
\text { Global Climate Data (2016) }\end{array}$ & $>1200$ & $600-1200$ & - & $<600$ \\
\hline Incidence of frost & $\begin{array}{l}\text { Derived from WorldClim - } \\
\text { Global Climate Data (2016) }\end{array}$ & $<0.4$ & $0.4-0.59$ & $0.59-0.8$ & $>0.8$ \\
\hline \multicolumn{6}{|l|}{ Land \& Soil } \\
\hline Slope in \% & $\begin{array}{l}\text { Derived from ESRI Terrain } \\
\text { Service }\end{array}$ & $<10$ & $10-15$ & $15-30$ & $>30$ \\
\hline Drainage & $\begin{array}{l}\text { Harmonized World Soil } \\
\text { Database (version 1.2), } \\
\text { (2012) }\end{array}$ & $\begin{array}{l}\text { Well or } \\
\text { moderately well }\end{array}$ & $\begin{array}{l}\text { imperfectly or } \\
\text { somewhat } \\
\text { excessive }\end{array}$ & - & $\begin{array}{l}\text { Very poor, poor } \\
\text { or excessive }\end{array}$ \\
\hline Texture (\% wt. clay) & $\begin{array}{l}\text { Harmonized World Soil } \\
\text { Database (version 1.2), } \\
(2012)\end{array}$ & $15-20$ & $20-35$ or $10-15$ & $35-50$ & $>50$ or $<10$ \\
\hline $\begin{array}{l}\text { Coarse fragments } \\
(\mathrm{vol} \%)\end{array}$ & $\begin{array}{l}\text { Harmonized World Soil } \\
\text { Database (version 1.2), } \\
(2012)\end{array}$ & $<10$ & $10-15$ & $15-20$ & $>20$ \\
\hline Soil depth $(\mathrm{cm})$ & $\begin{array}{l}\text { Harmonized World Soil } \\
\text { Database (version 1.2), } \\
(2012)\end{array}$ & $>120$ & $80-120$ & $40-80$ & $<40$ \\
\hline $\begin{array}{l}\text { Acidity of top soil } \\
(\mathrm{pH})\end{array}$ & $\begin{array}{l}\text { Harmonized World Soil } \\
\text { Database (version 1.2), } \\
(2012)\end{array}$ & $6-6.5$ & $6.5-7$ or $5.5-6$ & $5-5.5$ or $7-7.5$ & $<5$ or $>7.5$ \\
\hline $\begin{array}{l}\text { Soil salinity ECe } \\
(\mathrm{dS} / \mathrm{m})\end{array}$ & $\begin{array}{l}\text { Harmonized World Soil } \\
\text { Database (version 1.2), } \\
(2012)\end{array}$ & $<0.15$ & $0.15-2$ & $2-4$ & $>4$ \\
\hline
\end{tabular}

Table A3: Business and compliance suitability of hazelnut production and sourcing (based on authors classification).

\begin{tabular}{|c|c|c|c|c|c|}
\hline Criteria & Data source & S1 & $\mathbf{S 2}$ & S3 & $\mathbf{N}$ \\
\hline \multicolumn{6}{|l|}{ Business suitability } \\
\hline Ease of doing business (Rank) & $\begin{array}{l}\text { The World Bank } \\
\text { Group (2017) }\end{array}$ & $1-100$ & $101-135$ & $136-176$ & $177-189$ \\
\hline Minimal Wages (US \$/month) & $\begin{array}{l}\text { OECD. Stat } \\
(2014)^{1}\end{array}$ & $1-499$ & $500-1499$ & $1500-2999$ & $>3000$ \\
\hline $\begin{array}{l}\text { Import Taxes per } 100 \mathrm{~kg} \\
\text { Hazelnuts to Switzerland }\end{array}$ & $\begin{array}{l}\text { Eidgenössische } \\
\text { Zollverwaltung } \\
\text { EZV (2017) }\end{array}$ & CHF 0.00 & CHF 10.00 & - & - \\
\hline \multicolumn{6}{|l|}{ Compliance suitability } \\
\hline $\begin{array}{l}\text { Worldwide Governance } \\
\text { Indicator (Average Rank) }\end{array}$ & $\begin{array}{l}\text { The World Bank } \\
\text { Group (2016) }\end{array}$ & $80.01-100.00$ & $30.01-80.00$ & $10.01-30.00$ & $0-10.00$ \\
\hline Risk of Child Labor & $\begin{array}{l}\text { Social Hotspot } \\
\text { Database } \\
(2016 a)\end{array}$ & $\begin{array}{l}\text { No evidence/ } \\
\text { Low/Medium }\end{array}$ & High & Very High & - \\
\hline Risk of Forced Labor & $\begin{array}{l}\text { Social Hotspot } \\
\text { Database } \\
(2016 b)\end{array}$ & Low/Medium & High & Very High & - \\
\hline $\begin{array}{l}\text { Risk of wage being under } 2 \$ \\
\text { per day }\end{array}$ & $\begin{array}{l}\text { Social Hotspot } \\
\text { Database, } \\
(2016 \mathrm{c})\end{array}$ & Low/Medium & High & Very High & - \\
\hline
\end{tabular}

${ }^{1}$ Futher sources: Alhamad, 2014; Arab Trade Union Confederation, n.d.; ConstructAfrica, 2014; EFFAT / PECO-Institut e. V., 2007; OECD. Stat, 2014; Quandl, 2014; The World Bank Group, 2017; WageIndicator, 2017; Wikipedia, 2015 
Table B1: Biophysical requirements of soybean, Glycine max L. Merrill. (adapted from FAO, 2007; Meena et al., 2014; Sudaryono et al., 2011; Sys et al., 1993; Wang, 1994)

\begin{tabular}{|c|c|c|c|c|c|c|}
\hline Criteria & Data Source & S1 & S2 & $\mathbf{S 3}$ & $\mathbf{N}$ & $\begin{array}{l}\text { impro } \\
\text { vable }^{2}\end{array}$ \\
\hline \multicolumn{7}{|l|}{ Climate } \\
\hline $\begin{array}{l}\text { Prec. of the } 1 \text { st month } \\
(\mathrm{mm})\end{array}$ & $\begin{array}{l}\text { WorldClim - Global Climate Data } \\
\text { (2016) (precipitation) }\end{array}$ & $60-275$ & $\begin{array}{l}275-400 \text { or } \\
60-50\end{array}$ & $400-475$ & $\begin{array}{l}>475 \text { or } \\
<50\end{array}$ & - \\
\hline $\begin{array}{l}\text { Prec. of the } 2 \text { nd month } \\
(\mathrm{mm})\end{array}$ & $\begin{array}{l}\text { WorldClim - Global Climate Data } \\
\text { (2016) (precipitation) }\end{array}$ & $115-275$ & $\begin{array}{l}275-400 \text { or } \\
115-80\end{array}$ & $\begin{array}{l}400-475 \text { or } \\
80-50\end{array}$ & $\begin{array}{l}>475 \text { or } \\
<50\end{array}$ & - \\
\hline $\begin{array}{l}\text { Prec. of the 3rd month } \\
(\mathrm{mm})\end{array}$ & $\begin{array}{l}\text { WorldClim - Global Climate Data } \\
\text { (2016) (precipitation) }\end{array}$ & $115-275$ & $\begin{array}{l}275-400 \text { or } \\
115-80\end{array}$ & $\begin{array}{l}400-475 \text { or } \\
80-50\end{array}$ & $\begin{array}{l}>475 \text { or } \\
<50\end{array}$ & - \\
\hline $\begin{array}{l}\text { Prec. of the 4rd month } \\
(\mathrm{mm})\end{array}$ & $\begin{array}{l}\text { WorldClim - Global Climate Data } \\
\text { (2016) (precipitation) }\end{array}$ & $60-275$ & $\begin{array}{l}275-400 \text { or } \\
60-40\end{array}$ & $\begin{array}{l}400-475 \text { or } \\
<40\end{array}$ & $>475$ & - \\
\hline $\begin{array}{l}\text { Mean. temp. of growing } \\
\text { cycle }\left({ }^{\circ} \mathrm{C}\right)\end{array}$ & $\begin{array}{l}\text { WorldClim - Global Climate Data } \\
\text { (2016) (average temperature) }\end{array}$ & $20-30$ & $\begin{array}{l}20-18 \text { or } \\
30-35\end{array}$ & $\begin{array}{l}18-15 \text { or } 35- \\
40\end{array}$ & $<15$ or $>40$ & - \\
\hline $\begin{array}{l}\text { Mean min. temp. of } \\
\text { growing cycle }\left({ }^{\circ} \mathrm{C}\right)\end{array}$ & $\begin{array}{l}\text { WorldClim - Global Climate Data } \\
\text { (2016) (average temperature) }\end{array}$ & $>12.0$ & $12.0-9.0$ & $9.0-7.0$ & $<7$ & - \\
\hline $\begin{array}{l}\text { Rel. humidity of devel. } \\
\text { stage - 2nd month (\%) }\end{array}$ & $\begin{array}{l}\text { (CliMond, 2014) } \\
\text { (rel. humidity at } 9 \mathrm{am})\end{array}$ & $42->80$ & $42-36$ & $36-30$ & $<30$ & - \\
\hline $\begin{array}{l}\text { Rel. humidity of } \\
\text { maturation stage }-4 \text { th } \\
\text { month }(\%)\end{array}$ & $\begin{array}{l}\text { (CliMond, 2014) } \\
\text { (rel. humidity at } 9 \text { am) }\end{array}$ & $24-75$ & $\begin{array}{l}24-20 \text { or } \\
75-85\end{array}$ & $<20$ or $>85$ & - & - \\
\hline $\begin{array}{l}\text { Sunshine dur. of devel. } \\
\text { stage - 2nd month }(\mathrm{n} / \mathrm{N})\end{array}$ & Derived from (CliMond, 2014) & $0.35-0.75$ & $\begin{array}{l}<0.35 \text { or } \\
>0.75\end{array}$ & - & - & - \\
\hline $\begin{array}{l}\text { Sunshine dur. of } \\
\text { maturation stage - } 4 \text { th } \\
\text { month }(\mathrm{n} / \mathrm{N})\end{array}$ & Derived from (CliMond, 2014) & $>0.7-0.5$ & $<0.5$ & - & - & - \\
\hline \multicolumn{7}{|l|}{ Land \& Soil } \\
\hline Slope $(\%)$ & $\begin{array}{l}\text { Derived from } \\
\text { Reuter et al., SRTM (2007) and } \\
\text { Tachikawa et al., ASTER GDEM } \\
(2011)\end{array}$ & $0-8$ & $8-16$ & $16-30$ & $>30$ & + \\
\hline Drainage & $\begin{array}{l}\text { Harmonized World Soil Database } \\
\text { (version 1.2), (2012) }\end{array}$ & $\begin{array}{l}\text { Moderately } \\
\text { well, well, } \\
\text { somewhat } \\
\text { excessive } \\
\text { or } \\
\text { excessive }\end{array}$ & imperfectly & poor & Very poor & + \\
\hline Texture/structure & $\begin{array}{l}\text { Harmonized World Soil Database } \\
\text { (version 1.2), (2012) }\end{array}$ & $\begin{array}{l}\text { Sandy clay } \\
\text { loam, silty } \\
\text { loam, silt, } \\
\text { clay loam } \\
\text { or silty clay } \\
\text { loam }\end{array}$ & $\begin{array}{l}\text { Sandy } \\
\text { loam, sandy } \\
\text { clay, clay }\end{array}$ & $\begin{array}{l}\text { Loamy sand, } \\
\text { silty clay }\end{array}$ & sand & - \\
\hline Coarse fragments (vol\%) & $\begin{array}{l}\text { Harmonized World Soil Database } \\
\text { (version 1.2), (2012) }\end{array}$ & $0-15$ & $15-35$ & $35-55$ & $>55$ & + \\
\hline Soil depth $(\mathrm{cm})$ & $\begin{array}{l}\text { Harmonized World Soil Database } \\
\text { (version 1.2), (2012) }\end{array}$ & $>75$ & $75-50$ & $50-25$ & $<25$ & - \\
\hline $\mathrm{CEC}(\mathrm{cmol}(+) / \mathrm{kg})$ & $\begin{array}{l}\text { Harmonized World Soil Database } \\
\text { (version 1.2), (2012) }\end{array}$ & $>25$ & $25-15$ & $15-5$ & $<5$ & + \\
\hline Base saturation (\%) & $\begin{array}{l}\text { Harmonized World Soil Database } \\
\text { (version 1.2), (2012) }\end{array}$ & $>35$ & $35-20$ & $<20$ & - & + \\
\hline Organic carbon $(\%)$ & $\begin{array}{l}\text { Harmonized World Soil Database } \\
\text { (version 1.2), (2012) }\end{array}$ & $>2.0-1.2$ & $1.2-0.8$ & $<0.8$ & - & + \\
\hline Soil acidity $(\mathrm{pH})$ & $\begin{array}{l}\text { Harmonized World Soil Database } \\
\text { (version 1.2), (2012) }\end{array}$ & $5.5-7.0$ & $\begin{array}{l}5.5-5.0 \text { or } \\
7.0-7.8 \\
\end{array}$ & $\begin{array}{l}5.0-4.5 \text { or } 7.8- \\
8.5 \\
\end{array}$ & $\begin{array}{l}<4.5 \text { or } \\
>8.5\end{array}$ & + \\
\hline Soil salinity ECe $(\mathrm{dS} / \mathrm{m})$ & $\begin{array}{l}\text { Harmonized World Soil Database } \\
\text { (version 1.2), (2012) }\end{array}$ & $0-2.0$ & $2.0-4.0$ & $4.0-5.0$ & $>5$ & - \\
\hline Current land use & $\begin{array}{l}\text { FAO - Food and Agriculture } \\
\text { Organization of the UN, LADA } \\
(2010)\end{array}$ & $\begin{array}{l}\text { Cultivated } \\
\text { terrestrial } \\
\text { areas and } \\
\text { managed } \\
\text { lands: } \\
\text { Irrigated } \\
\text { and rainfed } \\
\text { seasonal } \\
\text { cropped } \\
\text { areas } \\
\end{array}$ & $\begin{array}{l}\text { Permanentl } \\
\text { y cropped } \\
\text { area with } \\
\text { rainfed } \\
\text { shrub } \\
\text { crops, Post- } \\
\text { flooding } \\
\text { herbaceous } \\
\text { crop }\end{array}$ & $\begin{array}{l}\text { Natural open } \\
\text { shrub } \\
\text { vegetation, } \\
\text { Natural } \\
\text { herbaceous } \\
\text { vegetation, } \\
\text { Forest } \\
\text { Plantation, } \\
\text { Natural } \\
\text { grasslands }\end{array}$ & 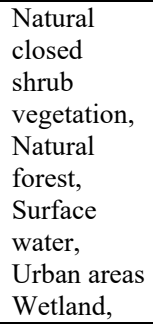 & \\
\hline
\end{tabular}

\footnotetext{
${ }^{2}$ If a parameter is improvable, it is not included in the assessment of potential suitability.
} 
Table B2: Farming system suitability of soya production in Rwanda (based on authors classification)

\begin{tabular}{|l|l|l|l|l|l|}
\hline Site Characteristic & Data Source & S1 & S2 & S3 & N \\
\hline \% of overall harvest sold & NISR*, 2012 & $\geq 26.0$ & $16.0-25.9$ & $1.0-15.9$ & $0.0-0.9$ \\
\hline $\begin{array}{l}\text { \% of households (HHs) } \\
\text { cultivating more than 0.9 ha }\end{array}$ & NISR*, 2012 & $\geq 16.0$ & $10.0-15.9$ & $4.0-9.9$ & $0.0-3.9$ \\
\hline$\%$ of HHs producing soya & NISR*, 2012 & $\geq 20.0$ & $10.0-19.9$ & $1.0-9.9$ & $0.0-0.9$ \\
\hline $\begin{array}{l}\text { \% of HHs incurring } \\
\text { expenditure on fertilizers }\end{array}$ & NISR*, 2015 & $\geq 40.0$ & $20.0-39.9$ & $1.0-19.9$ & $0.0-0.9$ \\
\hline
\end{tabular}

* National Institute of Statistics of Rwanda 


\section{Literature ANNEX}

Alhamad, H.S., 2014. The Labor Market in Saudi Arabia: Foreign Workers, Unemployment and Minimum Wage. Inq. Journal/Student Pulse $6,1-2$.

Arab Trade Union Confederation, 2016. Palestine: 137.8 Thousand Workers in Palestine are paid less than Minimum Wage [WWW Document]. URL http://www.arabtradeunion.org/en/content/palestine-1378-thousand-workers-palestine-are-paid-less-minimumwage (accessed 4.18.17).

CliMond, 2014. Climate Data [WWW Document]. URL http://www.ncdc.noaa.gov/cdo-web/datasets\#ANNUAL

ConstructAfrica, 2014. Construction workers' minimum wage gazetted in Namibia [WWW Document]. URL http://www.constructafrica.com/news/construction-workers-minimum-wage-gazetted-namibia (accessed 4.18.17).

EFFAT / PECO-Institut e. V., 2007. Wages and Labour Costs [WWW Document]. URL http://www.agri-info.eu/english/t_wages.php\#de (accessed 4.18.17).

Eidgenössische Zollverwaltung EZV, 2017. TARES. Tariff search. Tariff number 0802.2290 [WWW Document]. URL https://www.ezv.admin.ch/ezv/de/home.html?_organization=606 (accessed 6.6.17).

ESRI Terrain Service, n.d. ArcGIS [WWW Document]. URL https://www.arcgis.com/features/index.html

FAO - Food and Agriculture Organization of the UN, 2010. LADA Land Degradation Assessment in Drylands [WWW Document]. URL http://www.fao.org/nr/lada/

FAO - Food and Agriculture Organization of the UN, 2007. Ecocrop [WWW Document]. URL http://ecocrop.fao.org

Harmonized World Soil Database (version 1.2), 2012. FAO/IIASA/ISRIC/ISSCAS/JRCI [WWW Document]. URL http://www.iiasa.ac.at/Research/LUC/External-World-soil-database/HTML/SupplementaryData.html

Kidd, D., Webb, M., Malone, B., Minasny, B., McBratney, A., 2015. Digital soil assessment of agricultural suitability, versatility and capital in Tasmania, Australia. Geoderma Reg. 6, 7-21. doi:10.1016/j.geodrs.2015.08.005

Malone, B.P., Kidd, D.B., Minasny, B., McBratney, A.B., 2015. Taking account of uncertainties in digital land suitability assessment. PeerJ 3, 1-21. doi:10.7717/peerj.1366

Meena, G.L., Singh, R.S., Meena, S., Meena, R.H., Meena, R.S., 2014. Assessment of land suitability for soybean ( Glycine max ) in Bundi district, Rajasthan. Agropedology 24, 146-156.

National Institute of Statistics of Rwanda, 2015. Rwandan integrated household living conditions survey (EICV) 2013/2014. Main Indicators Report. Kigali, Rwanda.

National Institute of Statistics of Rwanda, 2012. Agriculture - EICV3 Thematic Report. Kigali, Rwanda.

OECD.Stat, 2014. Real minimum wages [WWW Document]. URL http://stats.oecd.org/Index.aspx?DataSetCode=RMW (accessed 9.8.15)

Olsen, J., 2013. Growing Hazelnuts in the Pacific Northwest. Orchard Nutrition. Corvallis, Oregon.

Quandl, 2014. Minimum wage by country [WWW Document]. URL https://www.quandl.com/collections/economics/minimum-wage-bycountry (accessed 7.31.15).

Reuter, H.., Nelson, A., Jarvis, A., 2007. An evaluation of void filling interpolation methods for SRTM data. Int. J. Geogr. Inf. Sci. 21, 9831008 .

Sarioglo, F.E., Saygın, F., Balcı, G., Dengiz, O., Demirsoy, H., 2013. Determination of potential hazelnut plantation areas based GIS model case study : Samsun city of central Black Sea region. Eurasian J. Soil Sci. 2, 12-18.

Snare, L., 2006. Pest and disease analysis in hazelnuts. Lester Snare, NSW Department of Primary Industries. Horticultural Australia Ltd., Sydney.

Social Hotspot Database, 2016a. Risk levels for "risk of child labor in sector, total (qualitative)" in vegetables, fruit, nuts sector [WWW Document]

Social Hotspot Database, 2016b. Risk levels for "risk of forced labor in country (qualitative)" in vegetables, fruit, nuts sector [WWW Document].

Social Hotspot Database, 2016c. Risk levels for "risk of wages being under \$2 per day" in vegetables, fruit, nuts sector [WWW Document]

Sudaryono, P., Wijanarko, A., 2011. Land Suitability for Developing Soybean Crops in Bumi Nabung and Rumbia Districts, Central Lampung. J. Trop. Soils 16, 85-92. doi:10.5400/jts.2011.16.1.85

Sys, C., Van Ranst, E., Debaveye, I.J., Beernaert, F., 1993. Crop Requirements, in: Land Evaluation. Part III. Agricultural Publications N7, 
Brussels, Belgium.

Tachikawa, T., Hat, M., Kaku, M., Iwasaki, A., 2011. Characteristics of ASTER GDEM Version 2. Geosci. Remote Sens. Symp. (IGARSS), 2011 IEEE Int. 3657-3660. doi:10.1109/IGARSS.2011.6050017

The World Bank Group, 2017. Doing Business 2017: Equal Opportunity for All. 14th ed. International Bank for Reconstruction and Development / The World Bank, Washington DC. doi:10.1596/978-1-4648-0948-4

The World Bank Group, 2016. Worldwide governance indicators [WWW Document]. URL http://info.worldbank.org/governance/wgi/index.aspx\#home

Ustaoğlu, B., 2012. The Effect of Climatic Conditions on Hazelnut (Corylus avellana) Yield in Giresun (Turkey). Marmara Cograf. Derg. Sayi 26, 302-323.

WageIndicator, 2017. Cyprus Minimum Wage -Frequently Asked Questions [WWW Document]. URL

http://www.wageindicator.org/main/salary/minimum-wage/cyprus/cyprus-minimum-wage-faq (accessed 4.18.17).

Wang, F., 1994. The use of artificial neural networks in a geographical information system for agricultural land-suitability assessment. Environ. Plan. A 26, 265-284. doi:10.1068/a260265

Wikipedia, 2015. List of minimum wages by country [WWW Document]. URL

https://en.wikipedia.org/wiki/List_of_minimum_wages_by_country (accessed 8.14.15).

WorldClim - Global Climate Data [WWW Document], 2016. WorldClim Version 2. URL http://worldclim.org/version2 